\title{
Yabancı Uyruklu Öğrencilerin Eğitimi ve Uyumu: Sorunlar ve Çözüm Önerileri ${ }^{1}$ \\ Education and Adaptation of Foreign Students: Problems and Suggestions
}

\begin{tabular}{l} 
Anahtar Kelimeler \\
\hline Göç, ĕ̌itim, yabancl, \\
uyruk, yabancı uyruklu \\
ögrenci.
\end{tabular}

Makale Hakkında

Gönd. Tarihi: 02/01/2021

Kabul Tarihi: 27.09.2021

Yayın Tarihi: 01.11.2021

Hasan SARIAHMETOĞLU ${ }^{2}$, S. Tunay KAMER ${ }^{3}$

\begin{abstract}
Ozet
Bu çalışmanın amacı; Kastamonu ilinde ortaokullarda öğrenim gören yabancı uyruklu ögrencilerin ĕgitim sistemine uyumunda ögretmenlerin ve okul yöneticilerinin karşılaştıkları sorunları tespit etmek ve bu konuyla ilgili yapılacak planlamalara katkı sunmaktır. Bu çalışma, nitel bir araştırmadır. Durum çalışması desenine göre yürütülen bu araştırmanın verileri yarı yapılandırılmış görüşme formlar ile toplanmıştır. Veriler, 2018 yılında Kastamonu ilinde 4 ortaokulda görev yapan 8 ögretmen ve 8 okul yöneticisiyle yapılan görüşmelerden elde edilmiştir. Ses kaydına alınan görüssmelerden elde edilen verilerin çözümlenmesinde betimsel analiz yöntemi kullanılmıştır. Araştırma sonucunda; yabancı uyruklu öğrencilerin Türkçe bilmemeleri ögretmen ve yöneticilerin karşılaştığ en önemli sorun olarak ortaya çıkmıştır. Bu sebeple ögrencilerin akademik anlamda başarısız oldukları ve ilk zamanlarda arkadaşları tarafından dışlandıkları okul yöneticileri ve ögretmenler tarafından ifade edilmiştir. Okullarda yabancı uyruklu öğrenci sayısının artmasıyla beraber çeteleşme ve şiddet olaylarının da arttı̆̆ belirtilmiştir. Bu öğrencilerde devamsızlık ve okul terkinin yüksek olduğu ve yabancı uyruklu öğrenci ailelerinin maddi sorunlar yaşadı̆̆ dile getirilen diğer sorunlar olmuştur. Denklik işlemleri yapılırken yaşlarından daha düşük sınıflara verilmesinin sorunlara yol açtığı ortaya çıkmıştır. Yabancı uyruklu ögrencilerin bazı okullarda yığılması sorunların çoğalmasına ve yeni sorunların ortaya çıkmasına sebep olduğu okul yöneticileri ve ögretmenler tarafindan ifade edilmiştir.
\end{abstract}

\section{Abstract}

This study aims to determine the problems faced by students, teachers and school administrators in the adaptation of the foreign students studying in secondary schools in Kastamonu province to the education system and to identify solution related to these problems. This study is a qualitative research. Face-to-face

\section{$\underline{\text { Key Word }}$}

Immigration, education, foreign, nationality, foreign students interview method was used through Multiple Holistic Case Study. The data were obtained from the interviews with eight teachers and eight administrators in Kastamonu province in 2018. Interviews were conducted through a semi-structured interview form prepared by the researcher. Descriptive analysis method was used to analyze the data of the audio recorded interviews. According to the research results, it became clear that foreign students' poor command of Turkish is the most important problem encountered by students, teachers and principals. For this reason, these students fail academically and are initially excluded by their friends. With the increase in the number of foreign students in schools, the incidence of violence and gang involvement increases among students. It was found that the absenteeism rate and dropout rate of these students are high and the families of these students are in financial difficulties. It was observed that the enrollment of foreign students in the underage ranking classes during the equivalence procedures caused some problems, too. The mass of foreign students in some particular schools has increased the problems and caused new ones.

Atıf için: $\quad$ Sarıhmetoğlu, H. ve Kamer, S. T. (2021). Yabancı uyruklu öğrencilerin eğitimi ve uyumu For Citation Sorunlar ve çözüm önerileri. Muğla Sitkı Koçman Üniversitesi Eğitim Fakültesi Dergisi [MSKU Journal of Education] 8(2), 612-634. DOI: 10.21666/muefd.852569

\footnotetext{
${ }^{1} \mathrm{Bu}$ makale, birinci yazarın ikinci yazar danışmanlığında tamamladığı yüksek lisans tezinden üretilmiştir.

${ }^{2}$ MEB, Şube Müdürü, hasan371976@gmail.com, ORCID: 0000-0002-6468-4312

${ }^{3}$ Doç. Dr., Kastamonu Üniversitesi Eğitim Fakültesi, tunaykamer@ gmail.com, ORCID: 0000-0002-1504-1273
} 
Mülteciler, savaş, çatışma veya siyasi huzursuzluk gibi insan yapımı krizler veya salgın hastalıklar, seller, kasırgalar, kuraklık, kıtlık veya depremler gibi doğal afetler nedeniyle aniden anavatanlarından koparılmış gruplar veya milliyetlerdir. On yıllardır, bu insan yapımı felaketlerin tutarlılı̆̆ ve yoğunluğu, insanların afetten etkilenen anavatanlarından yeni ev sahibi ülkelere topluca yerinden edilmesine ve kitlesel hareketine neden olmuştur (Pennells ve Ezeomah, 2002).

Son yıllarda Türkiye'nin karşı karşıya kaldığı yoğun göçün sonucu olarak göçle gelenlerin eğitimi ve topluma uyum süreci önemli bir konu haline gelmiştir. Ancak yapılan araştırmalar göstermektedir ki eğitim, göç eden aileler için öncelikli konular içinde yer almamaktadır. Onlar için önemli olan ekonomik ihtiyaçlardır. Göç edenlerin düzenli ve belirli bir işe sahip olmamaları onların ekonomik olarak sıkıntı ve problemler yaşamalarına sebep olmaktadır. Yaşanan bu durum çocukları da etkilemektedir. Çocuklar zorunlu olarak küçük çaplı işlerde çalışmakta, aile bütçesine destek sağlamaktadırlar. Çocukların çalışarak aile bütçesine katkı sağlaması onların temel sorumluluklarını yerine getirmelerini büyük ölçüde engellemektedir (Kaştan, 2015).

Stevenson ve Willot (2007), mülteci çocukların eğitim almasını engelleyen yoksulluk, travma deneyimi, şiddet, tehdit, kesintili eğitim, dil güçlüğü gibi birçok faktör olduğunu belirtmişlerdir. Mülteci deneyimi herkes için farklıdır, bu yüzden genelleştirilmesi doğru değildir. Aslına bakılırsa, sığınma, barış ve güvenlik aradıkları ülkelerde bütün mültecilerin karşılaştığı benzer zorluklar bulunmaktadır (Stuecker, 2006).

Göçmen aileler geldikleri ülkede kültürel ve sosyal ortama uyum sağlamak amacıyla mücadele ederler. Göçmen çocuklar da sadece yeni sosyokültürel çevreye değil, aynı zamanda göç ettikleri ülkenin eğitim sistemine de uyum sağlamak için çaba göstermektedirler. Özellikle çocuklar için yeni başlayan bu hayat onların ruh sağlığında bozulmalara neden olabilmektedir. Yani göç, çocuk ve ergen açısından çeşitli riskler içermektedir. Göçe maruz kalan çocuk ve ergenlerde uyum sorunları oluşabilmektedir. Bu durum çocukların eğitimlerine de yansımakta ve bu çocuklar göç ettikleri yerlerdeki okullarda çeşitli problemlerle karşılaşmakta ve zorluklar yaşamaktadırlar (Nar, 2008).

Sayın, Usanmaz ve Aslangiri'nin (2016) araştırma verilerine göre sığınmacı çocukların büyük bir çoğunluğu sığındıkları ülkedeki eğitime devam ettikleri okullarda, ayrımcılık, maddi imkânsızlık, dil ve arkadaş edinememe gibi sorunlarla karşı karşıya kalmaktadır. Bu durum sığınmacı çocukların sağlıklı bir eğitim sürecinden geçmelerini ve tanıştıkları yeni kültüre uyumlarını engellemektedir. Bunun sonucunda da küçük yaşlarda sığınmacı çocuklarda dışlanma ve ait olamama duygusu hâkim olabilmektedir. Dupper'e (2002) göre okullar, öğrencilerin eğitildiği ve sosyalleştiği üretim alt sisteminin temel parçasını oluşturmaktadır. Göçmenler için eğitimin önemi, göçmenlerin yerleştiği ülkeye uyumunu kolaylaştırması, 1rk ayrımcılığının ve göçmenlere karşı önyargının eğitim yoluyla en aza indirilmesidir (Baker, 2011).

Son yıllarda komşu ülkelerde ve özellikle Suriye'de meydana gelen karışıklıklar sebebiyle Türkiye'ye yönelen göç akını başlangıçta geçici olarak görülmüş ve sığınmacılara yönelik uzun vadeli politikalar üretilmemiştir (Özcan, 2018). Bu algının eğitim alanında da kendisini gösterdiğini görmekteyiz.

Bugün ülkemize çeşitli sebeplerle göç etmiş yabancı uyruklu öğrencilere Türk öğrencilerle beraber aynı okul ve sınıflarda eğitim verilmektedir. Bu öğrencilerin seviyeleri düşünüldüğünde Türkiye'deki öğrenciler ile aynı müfredatı herhangi bir yardım almadan öğrenmeleri çok zordur. Kültürel olarak farklı oldukları ve uzun süre savaş içinde yaşadıkları düşünüldüğünde bu öğrencilerin ön öğrenmelerinin büyük oranda eksik olduğu da görülmektedir. Dolayısıyla bu öğrencilerin seviyelerinin belirlenerek buna göre bir eğitim içeriği sunulmalıdır. Öğretmenler, diğer öğrencilerden farklı olarak yabancı öğrencilerin dille ilgili sorunlarını kişisel gayretleriyle çözmeye çalışmaktadırlar. Dil engeli yanında yabancı öğrencilerin sahip oldukları farklı kültürler, göç sürecinde okuldan uzak kalmaları ve bazılarının hiç okula başlamamış olması gibi durumlar da göç edilen ülkedeki okulları, öğrencileri ve öğretmenleri olumsuz olarak etkilemektedir (Erdem, 2017).

Göçmenlere yönelik uygulanan eğitim programları hayat boyu öğrenmeyi destekleyecek bir biçimde olması gerekmektedir. Bunun için göçmenlere yönelik meslek edindirme programlarının hazırlanması gerekir. Böylece ileriki zamanda göçmenlerin kalıcı hale gelmesi ve ülkeye yerleşmesi durumunda toplum ve iş hayatına uyumu daha kolay sağlanabilecektir. Bu yapılmadığı zaman göçmenlere yönelik bütün harcamalar devletin yükümlülüğü altında kalacaktır. Ülkemize gerçekleşen göçlerin büyük bölümünün kalıcı olduğu, pek azının geri döndügü unutulmamalıdır (Tuncer, 2016). 
Göçmenlerin Türkiye'deki sayı ve çeşitliliği verilecek eğitim hizmetlerinin niteliğini de farklılaştırmaktadır. Savaş travması yaşayan değişik yaş gruplarındaki genç ve çocuklara eğitim hizmetlerinin yanı sıra psikolojik yardım faaliyeti de yürütülmelidir (Tuncer ve Dikmen, 2017).

$\mathrm{Bu}$ konudaki çalışmalar incelendiğinde çalışmaların daha çok ilkokul (Solak ve Çelik, 2018; Delen, 2018; Emiroğlu Erol, 2018; Turan ve Polat, 2017; Sarıtaş, Şahin ve Çatalbaş, 2016; Güngör ve Şenel, 2018; Şensin, 2016) düzeyinde yapıldığı görülmektedir. Ortaokul (Duygu, 2016; Zayimoğlu Öztürk, 2018) düzeyinde yapılan çalışmalar da bulunmaktadır. Bu çalışmalarda genel olarak öğretmen

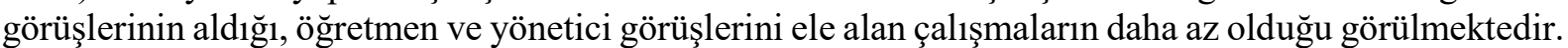
Bütün bu durumlardan hareketle araştırmanın problem cümlesini "Kastamonu ilinde ortaokul düzeyinde ĕgitim gören yabancı uyruklu öğrencilerin eğitim sistemine uyumunda karşılaşılan sorunlar ve bu sorunlarla ilgili ögrretmen ve okul yöneticilerinin görüşleri nelerdir? ” sorusu oluşturmaktadır.

Genelde ülkemizde özelde de Kastamonu'da yabanc1 uyruklu aile sayısı günden güne artmaktadır. Kastamonu'da bu ailelerin çocuklarının eğitim faaliyetleri, okullarda Türk öğrencilerle birlikte yapılmaktadır. Yabancı uyruklu öğrencilerin olduğu okullarda bu durumdan dolayı çeşitli problemlerin olması muhtemeldir. Bu araştırmanın amacı öğretmen ve okul yöneticilerinin görüşlerine göre yabancı uyruklu ögrencilerin eğitim sistemine uyumunda karşılaşılan sorunları ve önerileri belirlemektir.

\section{Yöntem}

$\mathrm{Bu}$ araştırma nitel yöntem ve durum çalışması yaklaşımı ile yapılmıştır. Durum çalışması, Creswell'e (2013) göre araştırmacının gerçek yaşam, güncel sınırlı bir sistem (durum) veya belli bir zaman içerisindeki çoklu sınırlandırılmış sistemler hakkında gözlemler, mülakatlar, görsel-işitsel materyaller ve dokümanlar ve raporlar vb. çoklu bilgi kaynakları aracılığıyla detaylı ve derinlemesine bilgi topladığı betimlemedir. Akar'a (2016) göre de durum çalışması araştırmacıya bir olaya müdahale etmeden derinlemesine inceleme, anlama, birey, katılımcı veya toplum üzerindeki etkisi veya ilişkisi konusunda çıkarımlarda bulunma imkânı verir.

\section{Çalıșma Grubu}

Araştırmanın çalışma grubunu Kastamonu il merkezinde bulunan Milli Eğitim Bakanlığına bağlı 4 ortaokuldaki 8 öğretmen ve 8 okul yöneticisi oluşturmaktadır.

Çalışmada amaçlı örnekleme yöntemlerinden ölçüt örnekleme yöntemi kullanılmıştır. Patton'a (2014) göre, bu örneklemenin amacı daha önceden belirlenmiş bazı önem ölçütlerini karşılayan bütün durumları çalışmak ve gözden geçirmektir. Bu ölçüt veya ölçütler araştırmacı tarafından oluşturulabilir ya da önceden hazırlanmış bir ölçüt listesi dikkate alınabilir (Yıldırım ve Şimşek, 2006). Kastamonu Milli Eğitim Müdürlüğ̈̈nden alınan bilgi doğrultusunda Milli Eğitim Bakanlığı Bilişim Sistemleri (MEBBİS) verilerine göre Kastamonu il genelinde ortaokul düzeyinde en çok yabancı uyruklu öğrenciye sahip olma durumu ölçüt olarak belirlenmiş ve okullar buna göre seçilmiştir. Öğretmenlerin seçiminde ise; çalışmaya dâhil edilen bu dört okulda görev yapan ve görüşme yapmayı kabul edenler arasından değişik branşlarda olmasına ve sınıflarında yabancı uyruklu öğrenci olmasına dikkat edilmiştir. Görüşme yapılan yöneticiler ise seçilen dört okuldaki müdür ve müdür yardımcılarından oluşmaktadır. Katılımcı grubundaki yönetici ve öğretmenlerin kişisel özellikleri Tablo 1'de sunulmuştur.

Tablo 1'de de görüleceği üzere araştırmaya Din Kültürü ve Ahlak Bilgisi, Matematik, Türkçe, Teknoloji ve Tasarım, İngilizce ve Fen Bilimleri branşından öğretmenler katılmıştır. Görüşülen kadın ve erkek öğretmen sayısı eşittir. Öğretmenlerin mesleki kıdemleri 5 ile 23 yıl arasında değişmektedir. Bulundukları okuldaki çalışma süreleri ise 1,5 yılla 14 yıl arasındadır.

Görüşülen yöneticilerin ise Matematik, Türkçe, Sosyal Bilgiler ve Teknoloji ve Tasarım branşlarında olduğu görülmektedir. Görev unvanlarına bakıldığında müdür yardımcısı olarak çalışanların çoğunlukta olduğu görülmektedir. Yöneticilerin toplam kıdem yılları 7-30 yıl arasıdır. Buna göre görüşme yapılanlardan bir kişi hariç tamamı 16 yıl ve üzeri kıdeme sahiptir. Bulundukları okuldaki yöneticilik süreleri 2-8 yıl arasıdır. 
Tablo 1

Kişisel Özelliklere İlişkin Bilgiler

\begin{tabular}{|c|c|c|c|}
\hline Özellik & & Yönetici & Öğretmen \\
\hline \multirow{7}{*}{ Branş1 } & Matematik & 1 & 2 \\
\hline & Türkçe & 3 & 2 \\
\hline & Din Kültürü ve Ahl. B. & - & 1 \\
\hline & Teknoloji ve Tasarım & 1 & 1 \\
\hline & İngilizce & - & 1 \\
\hline & Fen Bilimleri & - & 1 \\
\hline & Sosyal Bilgiler & 3 & - \\
\hline \multirow{2}{*}{ Cinsiyeti } & Kadın & 1 & 4 \\
\hline & Erkek & 7 & 4 \\
\hline \multirow{6}{*}{ K1dem Y111 } & $1-5$ & - & 1 \\
\hline & $6-10$ & 1 & - \\
\hline & $11-15$ & - & 3 \\
\hline & $16-20$ & 4 & 2 \\
\hline & $21-25$ & 1 & 2 \\
\hline & $26-30$ & 2 & \\
\hline \multirow{3}{*}{$\begin{array}{l}\text { Okulundaki } \\
\text { Görev/Yöneticilik Süresi }\end{array}$} & $1-5$ & 5 & 4 \\
\hline & $6-10$ & 3 & 3 \\
\hline & $11-15$ & - & 1 \\
\hline \multirow{2}{*}{ Okulundaki Görevi } & Müdür & 3 & - \\
\hline & Müdür Yardımcısı & 5 & - \\
\hline
\end{tabular}

\section{Veri Toplama Araçları}

$\mathrm{Bu}$ araştırmada veriler, yarı yapılandırılmış görüşme (mülakat) formları kullanılarak toplanmıştır. Görüşme, sözlü iletişim yoluyla veri toplama tekniğidir. İnsan yaşamında görüşmenin önemli ve o kadar da eski bir yeri vardır. Görüşme, bireylerin çeşitli konulardaki bilgi, düşünce, tutum ve davranışları ile bunların olası nedenlerinin öğrenilmesinde en kestirme yol olarak kullanılagelmiştir (Karasar, 2015). Büyüköztürk, Kılıç Çakmak ve Demirel'e (2009) göre yarı yapılandırılmış görüşmeler, hem basit seçenekli cevaplamayı hem de ilgili alanda derinlemesine gidebilmeyi birleştirir. Görüşme yöntemi, görüşülene kendini ifade etme imkânı ve derinlemesine bilgi sağlama gibi avantajlar da sağlamaktadır. Araştırmada, iki ayrı görüşme formu kullanılmıştır. Görüşme formları öğretmen ve okul yöneticilerine farklı olarak hazırlanmıştır. Öğretmenler için hazırlanan görüşme formunda kişisel özelliklerle ilgili 5 soru, yabanc1 uyruklu öğrencilerin eğitiminde karşılaşılan sorunlar ve çözüm yöntemleriyle ilgili 12 soru bulunmaktadır. Yöneticiler için hazırlanan görüşme formunda ise kişisel özelliklerle ilgili 5 soru yabancı uyruklu öğrencilerin eğitiminde karşılaşılan sorunlar ve çözüm yöntemleriyle ilgili 13 soru bulunmaktadır. Araştırmada kullanılan görüşme sorularının amaca uygun olmasına dikkat edilmiş, tamamen yansız, açık ve anlaşılır sorular hazırlanmıştır. Bu çerçevede problem cümlelerine uygun olarak soru havuzu oluşturulmuş, hazırlanan taslak görüşme formu kapsam geçerliliği için 4 öğretim üyesinin görüşüne sunulmuştur. Alınan geribildirim, görüş ve önerilere göre sorular yeniden düzenlenmiştir. Sonrasında çalışma grubunda yer almayan 2 okul yöneticisi ve 2 öğretmen ile görüşme formlarına pilot çalışma uygulamaları yapılmış, anlaşılmayan sorular formlardan çıkarılmıştır.

\section{Verilerin Toplanma Süreci}

Kastamonu İl Milli Eğitim Müdürlüğü ile yapılan yazışmalar sonucunda gerekli yasal izinler alınmıştır. Sonrasında araştırmanın yapılacağı okul türlerine ve okullara karar verilmiştir. Okul yönetimleri ile görüşme yapılarak ögretmenler için uygun zaman ve mekân seçilmiş ve görüşmeler 16-29 Mayıs 2018 tarihleri arasında gerçekleştirilmiş̧ir.

Öğretmen ve yöneticilerle yapılan görüşmeler yüz yüze ve bireysel görüşme şeklinde gerçekleştirilmiştir. Görüşme formlarında yer alan sorular, seçilen 4 okuldan 2'şer öğretmen ve 2'şer yöneticiye sorulmuştur. Görüşmeciler belirlenirken gönüllülük esası gözetilmiştir. Görüşme öncesinde, görüşmenin amacı, içeriği, yöntemi vb. hususlarda görüşmeciler bilgilendirilmiş, ses kaydı alınacağı 
konusu belirtilerek görüşmecilerin rızaları alınmıştır. Ayrıca görüşmecilerin kimliklerinin gizli tutulacağı, araştırmaya ilişkin hiçbir raporda ve yayında kişi isimlerinin kullanılmayacağı ifade edilmiştir. Görüşme yapılırken her bir katılımcıya kodlar verilmiştir. Öğretmenler için (ÖĞRT1, 2, 3...), yöneticiler için ise (YÖN1, 2, 3...) kodları kullanılmıştır.

Araştırma sırasında öğretmenlerle yapılan görüşmelere ait ses kayıt süresi 104 dakika 25 saniye ve okul yöneticileriyle yapılan görüşmelerde ise 111 dakika 1 saniyedir. Görüşmelerin yazıya aktarıldıktan sonra ortaya çıkan sayfa sayılarına bakıldığında öğretmenler için 15 sayfa yöneticiler için 13 sayfadır.

\section{Verilerin Analizi ve Yorumlanması}

Araştırmanın verileri, betimsel analiz yöntemi kullanılarak analiz edilmiştir. Betimsel analizde, veriler görüşme ve gözlem süreçlerinde kullanılan sorular ya da boyutlar dikkate alınarak sunulabilir. Görüşülen ya da gözlenen bireylerin görüşlerini çarpıcı bir biçimde yansıtmak için doğrudan alıntılara yer verilir. $\mathrm{Bu}$ analizde, bulgular düzenlenmiş ve yorumlanmış bir biçimde okuyucuya sunmak amaçlanır. Bu amaç ile elde edilen veriler, önce sistematik ve açık bir biçimde betimlenir. Yapılan bu betimlemeler açıklanır ve yorumlanır, neden-sonuç ilişkileri irdelenir ve sonuçlara ulaşılır. Ortaya çıkan temaların ilişkilendirilmesi, anlamlandırılması ve ileriye yönelik tahminlerde bulunulması araştırmacının yapacağı yorumların boyutları arasında yer alabilir (Yıldırım ve Şimşek, 2016).

Öğretmen ve okul yöneticilerle yapılan görüşmelerin ses kayıtları Microsoft Office Word programında yazıya aktarılmıştır. Veriler, araştırma sorularından oluşturulan çerçeveye göre düzenlenmiş daha sonra veriler tanımlanmış ve gerekli yerlerde doğrudan alıntılara yer verilmiştir. Son aşamada ise bulguların yorumlanmasına geçilmiştir. Görüşmelerden aktarılan orijinal ifadelerin yanında parantez içinde verilen öğretmen ve okul yöneticisi kodları alıntıların kimden alındığını temsil etmektedir.

\section{Geçerlik ve Güvenirlik}

Nitel araştırmalarda "iç geçerlik" yerine "inandırıcılık", "dış geçerlik" yerine "aktarılabilirlik", "iç güvenirlik" yerine "tutarlılık" ve "dış güvenirlik" yerine "teyit edilebilirlik" kavramları kullanılmakta olup nitel araştırmalar nicel araştırmalarda kullanıldığı şekliyle güvenirlik peşinde değildir (Yıldırım ve Şimşek, 2016). Durum çalışmaların güvenirliğinin arttırılması için araştırmacı izlenen süreçleri açıkça tanımlamalı, ilgili dokümanlarla kanıt sağlamalı, araştırmayı sistem dâhilinde kademeli olarak gerçekleştirmeli ve sunmalıdır (Paker, 2015). Bu kapsamda araştırmanın "inandırııılığını" sağlamak için katılımcılardan bazıları meslektaşımız olduğundan ve daha önceden tanıdığımız için diğerleriyle de görüşme öncesinde yaptığımız sohbetlerle samimiyet sağlanmaya çalışılmış ve verilerin gerçeği yansıtması sağlanmıştır. Ayrıca veri toplama araçlarının geliştirilmesi, verilerin analizi ve yorumlanması sürecinde nitel araştırma yöntemlerinde uzmanlaşmış iki akademisyenin görüşlerine başvurulmuştur. Araştırmanın aktarılabilirliğini sağlamak için ayrıntılı betimleme yoluna gidilmiştir. Ayrıntılı betimleme "ham verinin ortaya çıkan kavram ve temalara göre yeniden düzenlenmiş bir biçimde okuyucuya yorum katmadan ve verinin doğasına mümkün olduğu ölçüde sadık kalınarak aktarılması" yaklaşımıdır (Yıldırım ve Şimşek, 2016). Nitel araştırmanın "tutarlılığı" araştırma sürecinde verilerin benzer süreçlerle toplanıp toplanmadığı; "teyit edilebilirliği" ise araştırmacının kendi konumunun ve varlığının araştırmayı etkilememesi, araştırma sürecindeki bütün verilerin, notların ve yapılan kodların saklanması ve gerektiğinde incelenmeye sunulması ile ilişkilidir (Yıldırım ve Şimşek, 2016). Bu araştırmada tutarlılık için görüşmelerde benzer yaklaşımla sorular sorulmuş ve kayıt altına alınmıştır. Teyit edilebilirlik için görüşmecilerin, araştırmacının konumundan ve varlığından etkilenmemesi konusunda gerekli hassasiyet gösterilmiş, veriler incelenebilecek şekilde saklanmıştır.

\section{Bulgular ve Yorum}

Bulgu ve yorumlar öğretmen ve yönetici görüşlerine göre iki ana başlık altında sunulmuştur.

\section{Öğretmen Görüssleri}

Elde edilen bulgular; İletişim, Akademik Başarı, Aile Desteği, Etnik gruplaşmalar, Maddi Sorunlar, Öğretmenlerin Motivasyonu ve Hizmet İçi Eğitim İhtiyacı başlıkları altında değerlendirilmiştir. 


\section{İletişim}

Öğrencilerin Türkçe bilmemeleri veya az biliyor olmalarının ne gibi sorunlar ortaya çıkardığını ve bu dil öğrenme sorununun nasıl aşıldığını ortaya çıkarmak amacıyla öğretmenlere sorulan sorulara verilen cevaplar şu şekildedir. Öğretmenlerin görüşleri genel olarak Türkçe bilmemeleri anlaşma sorunu ortaya çıkarıyor, öğrencilerin ders başarısı bu durumdan olumsuz etkileniyor, öğrenciler isteklerini anlatmakta zorlanıyorlar, devamsızlık yapıyorlar şeklindedir.

ÖĞRT4: "Durumu iyi olanlar kursa gidiyorlar. Bir iki öğrencinin dişarıdan dil bilgisi ile ilgili ders aldığını öğrendim. Çoğunda zaten Türkçeyi öğreneyim diye bir çaba yok. Okula sağllklı bir şekilde devam etmiyorlar. Bir eğitim almıyorlar. Buraya gezmeye gelir gibi geliyorlar."

ÖĞRT1:"Anlaşmak zor oluyor. Yani çocuklar ders başarısı açısından bir ilerleme kaydedemiyorlar. Geriden takip ediyorlar. ...okulumuzda çok fazla yabancı öğrenci olduğu için daha önceden gelenler Türkçeyi öğrenmiş oluyorlar. Onların aracıllğ ile onlarla anlaşabiliyoruz zaten. Türkçe ögrenme konusunda çok yetenekliler."

ÖĞTR3: "Illetişimsizlik sebebiyle en doğal en basit şeyler bile yanlış anlaşılabiliyor. Yabancı ögrencilerin en doğal isteklerinden bile kötü bir mana çıkartılabiliyor. Davranış problemleri de oluyor. Bunun sebebi de dil diye düşünüyorum." "Dil bilmemeleri sebebiyle isteklerini söyleyemiyorlar. Mesela oyun oynayacak "benimle oyun oynar misin?" diyemiyor. Top isteyecek "topu alabilir miyim?" diyemiyor. ...Özellikle Arap uyruklu olanlar branşımızın Din Kültürü olması sebebiyle Arapça olarak söyleyebiliyorlar. Bir nevi tercümanlık yapmış oluyoruz onlara ..."

ÖĞTR5: "Türkçeyi ögrenene kadar sinıfta oturuyorlar. Hiçbir iletişim kurmuyorlar. ...dil bilmiyorsa anlaşamiyorsan tabi iletemiyorlar. Onların dediğini biz anlamiyoruz. Bizim dediğimizi onlar anlamiyor. Ancak anlayan bir arkadaş olursa onlar sayesinde iletişim kuruyoruz. Ĕger dilimizi biliyorlarsa iletişim oluyor, sorunların iletiyorlar."

ÖĞRT6: "Bizim ders saylsal olduğu için rakamlarla filan bir şekilde. Yani az buçuk anllyorlar. Ama Türkçe derslerinde tabii anlamadıkları için zorlaniyorlar. Ya da bir şey ifade ederken zorlanıyorlar. Bir problem sorduğum zaman problemi anlamadiğı için çözmesine imkân olmuyor. O yüzden dil eğitimi olmayınca bence hiçbir şey olmuyor.

ÖĞRT8: "Sorunlarını ve isteklerini bize iletemiyorlar. Ancak başka sınıflarda dillerinden anlayan ögrenciler varsa onlar aracılı̆̆ıla sorunlarını dinliyoruz."

Yabancı uyruklu öğrencilerin Türkçe bilmemeleri anlaşma sorununu ortaya çıkardığı görülmektedir. Ayrıca özellikle sözel derslerde ders başarıyı düşürdüğü, öğrencilerde devamsızlık yapmaya sebep olduğu, öğrencilerin isteklerini anlatamadıkları, buna rağmen öğrencilerde Türkçe öğrenme ve eğitim alma çabasının olmadığı tespit edilmiştir. Türkçe bilmeme sorununun tercüman veya Türkçe bilen arkadaşları vasıtasıyla çözüldüğü görülmektedir.

\footnotetext{
Akademik Başarı

Yabancı uyruklu öğrencilerin derslerde başarı sağlayıp sağlayamadığı ve bu konuda yaşanan sorunları öğrenmek amacıyla ortaya çıkarmak amacıyla öğretmenlere sorulan sorulara verilen cevaplar şu şekildedir. Öğretmenler genel olarak; bizim öğrenciler gibi başarılı öğrenciler de var başarısız öğrenciler de var, bu öğrenciler başarısız ve okulun başarısını da aşağı çekiyor, az çocuklu ailelerin öğrencileri daha başarılı gibi görüşler ileri sürmüşlerdir.

ÖĞRT4: "Şimdi ülkemizde sınıfta kalma diye bir şey olmadiğı için bu çocuklar hiçbir şey yapmiyorlar. Dediğim gibi çoğu Türkçe bilmiyor. O yüzden hiçbir şey yapmadan sinıf geçtikleri için diğer çocukların tepkisine sebep oluyor. Bizim çocukların da motivasyonunu aşağı çekiyor Biz niye bir şeyler yapıyoruz diye onu sorguluyorlar. Tabii olumsuz etkileniyorlar. Yabancı ögrenciler sinifta genelde hiç ses çıarmadan oturuyorlar. Hiçbir şeye dâhil olmadan konuşmadan oturuyorlar. Çünkü Türkçe bilmiyorlar. Okulumuzun başarısını kesinlikle bu öğrenciler aşağl çekiyor."

ÖĞRT3: "Akademik olarak bakınca çocukların başarılı olanları da var, orta düzeyde olanları da var, zayıf olanları da var. Bu durum çocukların geldikleri ortam, yaşadıkları travma ve problemlerle alakalı. Mesela bizim Türk ögrenciler kadar Türkçe dersinde soru çözebilen öğrenciler de var. Ama hiç alakası olmayanlar da var. Bunu araştırdığımızda
} 
çocukların yaşadıkları, göç etmelerine sebep olan nedenlerin çocukları psikolojik olarak etkilediğini ve bunun da eğitime yansıdı̆̆ın görüyoruz."

ÖĞRT6: "Yine ayn bizim ögrencilerimizde olduğu gibi. Mesela geçen bir öğrencim vardı gayet matematiği iyiydi. Ama bu seneki ögrencilerimin matematikle hiç ilgisi yok. $O$ yüzden bence yine aynı şekilde Türklerde olduğu gibi öğrenciden ögrenciye değissiyor. İyi olan da var, kötü olan da var."

ÖĞRT1: "Çok iyi olanlar var. Mesela Afgan bir öğrencim takdir belgesi aldl. Yani çok iyi bir ögrenci. Derslerinde gayet iyi, sorumluluk sahibi, ödevlerini zamanında yapıyor. Başka sinıflarda da var, matematikte bizim Türk ögrenciler umursamıyor o ögrenmek için çaba sarf ediyor. Çabaları olmayanlar ögrenemiyorlar. Aslında isteyenlerin akademik başarllarl iyiye gidiyor. Mesela bir öğrencinin matematikte 86 notu var. Türkçe daha düşük. En iyi notu matematik. Matematik diğer derslere göre daha iyi olabiliyor."

ÖĞRT2: "Türkçe bilmiyor olmalarının en büyük sıkıntısını derslerde yaşıyoruz. Akademik olarak yaşıyoruz. Belki bir matematik yaşamaz, belki bir İngilizce yaşamaz. Çünkü Türkçe sonradan ögrenilebilecek yeni bir dil. Matematik ise daha çok sayllarla ilgili. Sayılar ise evrensel. Yani benim branşım olarak düşündüğümüzde herhangi bir akademik başarı sağlayamıyorlar. Ĕger ders evrensel Boyut taşlyorsa bu derste başarılı ama bizim dersimizde tamamen dile hakim olması gerektiği için yetersiz oluyor."

Yabancı uyruklu öğrencilerin içinde derslerinde başarılı olan öğrencilerin olduğu, bunun yanında başarısız öğrencilerin de olduğu görülmüştür. Yine ifade edilen görüşlere göre akademik başarılarının Türk öğrencilerden pek farklı olmadığı görüşü ortaya çıkmaktadır.

\section{Aile Desteği}

Yabancı uyruklu öğrenci ailelerinin bu öğrencilerin eğitim sürecinde ne gibi katkılarının olduğunu öğrenmek ve bu konuda yaşanan sorunları ortaya çıkarmak amacıyla öğretmenlere sorulan sorulara verilen cevaplar şu şekildedir. Öğretmenler genel olarak; az çocuklu ailelerin öğrencilerle ilgilendiğini veya diğer öğretmenler ailelerin öğrencilere eğitim sürecinde bir katkılarının olmadığını söylemişlerdir.

ÖĞTR5: “Ailelerini hiç okulda görmüyoruz. Hiç okula gelmiyorlar. Ancak özel bir durum olduğunda idareye geldiklerini görüyoruz. Başka bir zaman göremiyoruz. Çocuklar kendileri işlerini halletmeye çalışıyorlar. Aileleri çok destek olamıyorlar. Onlar da aynı şekilde Türkçe bilmiyorlar. Onlar da bizimle böyle bir şey olduğu zaman tercüman vasitasiyla iletişim kuruyorlar."

ÖĞRT6: "Hiçbir katkı sağlamıyorlar. Sadece çocuklarını okula bıraktılar. Ne gelen var ne giden. Hiç görmedik bile çoğunun ailesini."

ÖGGRT2: "Yabancı uyruklu ailelerin çocuk sayısı bu konuda çok önemli. Zaten en büyük problemlerden bir tanesi baktı̆̆ımızda bu. Ĕger ailede çocuk sayısı fazla ise çocukla ilgilenmiyorlar. Ama ailede çocuk sayısı azsa o çocuğun peşinde pervane oluyorlar. Ne gerekiyorsa yapıyorlar. 5. sinıfta bir öğrenci var, sinıfta yaptırdı̆̆ım etkinliği yapamayabiliyor. Ama eve verdiğim ödevi mükemmel yapıp geliyor. Evde baba yapıyor.

Mükemmel bir yardımcı. Ne gerekiyorsa sinır yok. Bir çocukları var, çok fark ediyor. Yani iki çocuk üç çocuğun üzerinde çocuğu olanlar ilgilenmiyorlar."

Yabancı uyruklu öğrencilerin ailelerinin eğitim sürecinde desteklerinin olmadığg öğretmenler tarafindan vurgulanmaktadir.

\section{Etnik gruplaşmalar}

Okulda yabancı uyruklu öğrencilerin bulunmasını Türk öğrencilerin nasıl karşıladığını, bu öğrencilere karşı bir tepki veya dışlamanın olup olmadığını öğrenmek amacıyla öğretmenlere sorulan sorulara verilen cevaplar şu şekildedir. Öğretmenler genel olarak; zaman zaman dışlanmaların olduğunu, Türk velilerden çok tepki olmadığını, Türk öğrencilerle aynı okulda beraber eğitim almalarının faydalı olacağı belirtmişlerdir.

ÖĞRT1: "Gördüğüm kadarlyla bir dışlanma yok. Uyumlular şu anda. İlk zamanlarda dışlama oluyordu. Istemiyorlardl, niye geliyorlar deniyordu. Türkiye'ye gelmeye başladıklarında, 3-4 yll öncesinde o zaman yaşanıyordu böyle şeyler. Ama artık onlar da alıştılar. Çünkü sürekli geliyorlar. Sayıları arttı. Sinıfların üçte biri neredeyse yabancı oldu. Artık öyle bir problem yok. Yani onlara yabancı gözüyle bakmıyorlar. Ben kendi 
açımdan söyleyeyim velilerden hiç tepki almadım. Olumlu da olumsuz da bir şey duymadım."

ÖĞTR5: "Bir dlşlanma olduğunu düşünmüyorum. Bizim okulumuzda böyle bir dişlama yok. Öğrencilerimizden de öğretmenlerimizden de herhangi bir dişlama yok. Velilerimizden de öyle bir tepki yani okulumuzda şu kadar yabancı ögrenci var niye var niye yok böyle bir tepki hiç görmedim. Böyle bir tepki yok"

ÖĞRT2: 'Hani bir söz vardır 'çocuklarım milleti olmaz' diye. Gerçekten çocukların milleti yok. Onlar nereden olduklarına hiç bakmadan hep beraber oyun oynayabiliyorlar. ...Illk başta şunu yaşadık. Bir tane olduklarında çok üzülüyorlardı. Çok yalnız kalıyorlardl. Tek öğrenci de bunu yaşadık. İki ögrencinin olması ideal. İki öğrenci birbiriyle arkadaşlık yapıyordu. Ama iki üç olduğunda gruba giriyor. Gruba girdiğinde problemler çılkmaya başlıyor."

ÖĞRT6: “...dışlanma olayının öğrenciden kaynaklandığını düşünüyorum. Bir sinıfta dışlanma yaşayan öğrenci var. Ama diğer sinıfta başka bir öğrencimiz var onu arkadaşları da öğretmenleri de çok seviyor. ...Velilerden herhangi bir tepki gelmedi, duyduğum herhangi bir tepki de yok. ...okulların ayrı olması gerekiyor. Çünkü çocuklar derste anlatılanları anlamıyorlar. Kendi aralarında konuşuyorlar ve çocuktur bunları sessizce tutamazsın. O yüzden de bence ayrı bir okulda eğitim görmeleri daha mantıklı." ÖĞRT7: “...bu öğrencinin fitratı ile de alakalı. Bizim normal ögrencilerimizde de sinıf içerisinde problem yaşadĭ̆ımız gibi yabancı ögrencilerde de bu tarz uyumsuz öğrenci olursa uyumsuzluk dil probleminden dolayı daha da artıyor. Şiddete dönebiliyor. Bu problemin nedeni sadece dil bilmemelerinden değil de daha önce geldikleri ülkede karşılaştıkları problem. Mesela oradaki savaş durumundan dolayı bombalama olup bir sakatlanma olduysa. Bunlardan dolayı bir kısmının psikolojileri bozuk geliyor ve uyum problemi yaşanabiliyor. ...bizim halkımızla, gelenek göreneğimizle kaynaşmaları için uyum sağlayabilmeleri için böyle karma eğitimin olması lazım. Ama ilk bir yıl bir hazırlık sınıfi gibi ayrı bir okulda eğitim görseler, Türkçeyi biraz daha iyi öğrenseler, ondan sonra normal okullara geçseler daha faydalı olur kanaatindeyim."

ÖĞTR3: "Türk öğrencilerle karma olmasının daha yararlı olacă̆ını düşünüyorum. Çünkü onların bizim okullarımızdan izole edilmesi toplumdan ve kültürden de izole edilmesine sebep olacak. Bunun da ileride sosyokültürel açıdan büyük sılkntılara neden olabileceğini düşünüyorum. Özellikle Milli Eğitim Bakanlığı'nın bu şekilde karma eğitime devam etmesi gerektiğini düşünüyorum."

Yabancı uyruklu öğrencilerin zaman zaman Türk arkadaşları tarafından dışlandığı yönünde görüşler olmakla birlikte birçok öğretmen dışlanmanın olmadığını ifade etmektedir. Velilerin ise yabancı öğrencilerin okulda bulunmasına bir tepkilerinin olmadığı anlaşılmaktadır. Yabancı uyrukluların yaşayış biçimleri onların kabullenilmesi konusunda belirleyici olduğu, yaşam standardı yüksek olanların kabullenilmesi daha zor olduğu görülmektedir. Yine bu ifadelerden anlaşılan çocuklar arasında karşılaştırmalar yapılmakta, yabancı uyruklu çocukların özgüvenlerinin daha yüksek olduğudur. $\mathrm{Bu}$ konuda, yaşanılan zorlukların çocukları özgüven konusunda güçlendirdiği söylenebilir. Ayrıca öğretmenlerin yabancı uyruklu öğrenciler için ayrı bir okul uygulamasına genelde olumlu bakmadıkları ancak bazı öğretmenlerde yabancı uyruklu ögrencilerin ayrı okulda eğitim almaları düşüncesinin var olduğu anlaşılmaktadır.

\section{Maddi Sorunlar}

Yabancı uyruklu öğrencilerin maddi anlamda bir sıkıntılarının olup olmadığını tespit etmek amacıyla öğretmenlere sorulan sorulara verilen cevaplar şu şekildedir. Öğretmenler genel olarak; maddi sıkıntılarının olmadığını devletin ve hayır kurumlarının yardımda bulunduğunu bazı öğretmenlerin ise aileden aileye değişiklik gösterdiğini ve bazı ailelerin maddi sıkıntı yaşadıklarını söylemişlerdir.

ÖĞTR5: "Bizim okulumuzda bulunan ögrencilerin maddi sıkıntısı yok gibi. Ders defterleri, materyalleri hepsinin var. Kiyafetleri temiz, ders araç gereçleri iyi. Ama duyduğumuz kadarıyla durumu kötü olanlarda varmış. Bunlar da devletimiz ve hayır kurumları tarafindan destekleniyor. İhtiyaçları gideriliyor." 
ÖĞRT7: "Bu şekilde bir sıkıntı bize pek yansımıyor. İlk geldikleri zaman belki kılık kıyafet konusunda çanta, kitap, defter konusunda bir sikıntı var gibi. Ama bu bir şekilde bir hafta on gün içerisinde çözülüyor. Yardım kuruluşlarından veya okul kanalıyla çözülüyor." ÖĞRT4: "Maddi problem yaşamıyorlar. Çünkü bakllyyorlar. Kim bakıyor? Devlet baklyor. Kendi ăğzlarından giyim çeki aldıklarını söylüyorlar. Üstümüz başımız, yiyeceğimiz geliyor şeklinde konuşuyorlar. Sekizinci sınıfta bir öğrenci babasinın niye çalışayım ki diye ifade ettiğini bile söyledi. Bizim bu ülkenin vatandaşı olarak böyle bir seçeneğimiz yok ama. Çocuğun kendi ifadesi."

ÖĞTR2 "Ülkemize gelenler çok farkl kesimlere ait insanlar. Bizim okulumuzun çevresinde ki yabancı ailelerin maddi durumları kötü. Bunun sebebi buralarda daha ucuz ev bulabiliyor olmaları ve daha kolay kabul ediliyor olmaları. Evlerde çok aile iç içe yaşıyor. Evimizin karşısında yaşayan bir aile gece gündüz perdelerini çekmeden hayatların devam ettiriyorlar. Var perde ama çekilmiyor. Eve girip çıkan kimdir? Nedir? Bilinmez. Çokfarklı bir yaşam tarzları da var. Bizim Okulumuzdaki yabancı Öğrencilerin çoğunun kendi öğrencilerimizden maddi durumlarının daha iyi olduğuna inanıyorum. Bizim ögrenciler onlardan daha gariban."

ÖĞTR3: "Maddi sıkıntı yaşlyorlar. Bu durum özellikle giyimlerinden, kllık kiyafetlerinden anlaşıllyyor. Maddi sıkıntı yaşayanların okul kıyafetleri eksik olabiliyor. Ders araç gereçleri, çantaları eksik olabiliyor. Yeme içme konusunda da sıkıntılara sebep oluyor maddi durumlarının kötü olması."

Öğretmenlerin görüşlerine göre genelde yabancı uyruklu öğrenciler ve ailelerinin maddi sıkıntılar yaşadığı, bu sıkıntıların devlet ve hayır kurumları tarafından yapılan yardımlarla büyük ölçüde giderildiği anlaşılmaktadır.

\section{Öğretmenlerin Motivasyonu ve Hizmet İçi Eğitim İhtiyacı}

Bu problemle ilgili öğretmen görüşleri iki başlık altında sunulmuştur.

\section{Motivasyon}

Yabanc1 uyruklu öğrencilerin bulunduğu okullarda çalışmanın öğretmenlerin motivasyonunu nasıl etkilediğini öğrenmek amaciyla öğretmenlere sorulan sorulara verilen cevaplar şu şekildedir. Öğretmenler genel olarak; olumlu veya olumsuz bir etkisinin olmadığını belirtmişlerdir.

ÖĞRT6: "Motivasyonumu etkilemiyor. Ama bazı ögrenciler var mesela hiç derse katılmıyor. Dersle hiç ilgisi yok. Konuşmuyor, misafir gibi geliyor gidiyor. Sadece burada süre dolduruyor. Zaten çoğu zaman devamsızlık yapıyorlar. Ama başka bir şubede Iranlı bir ögrencimiz var. Derse katılımı çok güzel."

ÖĞRT7: "Herhangi bir değişiklik olmuyor. Biz normal dersimizi her zamanki gibi anlatıyoruz. Tabii onların anlamaları için de biraz daha fazla gayret sarf etmemiz gerekiyor."

ÖĞRT8: "Yok, benim motivasyonumu etkilemiyor."

Yukarıdaki öğretmenler gibi motivasyonlarında bir etkilenme olmadığını söyleyenlerin yanında yabancı uyruklu öğrencilerin varlığından olumsuz olarak etkilendiğini ifade eden öğretmenler de vardır.

ÖĞRT4: "Olumsuz etkileniyorum. Yani onlarm da kendilerini buraya ait hissetmediklerini hissediyorum. Ben de onlara ait hissetmiyorum. Farkl kültürlerden gelen insanların kültürümüze zarar vereceğini düşünüyorum. O yüzden her türlü motivasyonumu etkiliyor."

ÖĞRT2: "Yabancı uyruklu ögrencilerin sayısı çok fazla olmadı̆̆ı müddetçe herhangi bir olumsuzluk yok. Ama yabancı uyruklu ögrenciler sayı olarak fazla olduklarında kendi aralarında konuşup etrafi tedirgin ediyorlar. Nihayetinde bir şey söylüyorlar ama anlamıyorsunuz ve grup halinde konuştuklarında siz onlara müdahale edemiyorsunuz. Müdahale edemediğinizde diğer öğrenci grubunun da dikkatinin dă̆llmasina sebep oluyor. Bu seneki 5. sinıflarımızda yabancı ögrenci sayısı çok fazla. Sinıf mevcutlarının 20 civarında olduğunu düşünürsek üçte bire denk geliyor. Bu üçte bir oran okulumuz durumunu düşündüğ̈̈müzde hem zekâ olarak hem sosyal çevre olarak olumsuz şartlarda yetişmiş çocuklar." 
Öğretmenlerin genel olarak yabancı uyruklu öğrencilerin varlığından olumlu veya olumsuz olarak etkilenmedikleri, ancak yabancı öğrenci mevcudunun fazla olduğu durumlarda istenmeyen davranışlar nedeniyle olumsuz etkilenmeler olduğu görülmektedir.

\section{Hizmet içi eğitim ihtiyacı}

Farklı ülkelerden ve kültürlerden gelen öğrencilerin bulunduğu okullarda çalışan öğretmenlerin bu öğrencilere eğitim verme konusunda bir hizmet içi eğitim alıp almadıklarını ve böyle bir eğitime ihtiyaç duyup duymadıklarını tespit etmek amacıyla öğretmenlere sorulan sorulara verilen cevaplar şu şekildedir. Öğretmenler genel olarak; böyle bir eğitim almadıklarını, eğitim almanın iyi ve faydalı olacağını söylemişlerdir.

ÖĞRT1: "Almadık ama alsak iyi olurdu. Şu anda biz onlara alıştık. Bundan sonra eğitim almanın bir faydası olmaz. Illk zamanlar belki iyi olurdu. Onlara nasıl yaklaşmalıyı, onlarla nasll uyum sağlayabiliriz, ögrencileri nasll birbirine uyumlu şey yapabiliriz diye. Ama artık bir uyum sikıntımız yok. Onların da bizim Türk ögrencilerimizden bir fark kalmadı. Daha kolay anlaşıyorlar bizlerle. Illk geldikleri yıllar biraz sıkıntı oluyordu ama şimdi gelen öğrencilerde pek sıkıntı yaşamıyoruz. Ĕger bir eğitim yapılacaksa, onların sinıfa uyumunu nasıl sağlayabiliriz? Bizim öğrencilerle arası nasıl uyumlu olabilir? Hani onlarla nasıl anlaşabiliriz? Nasıl yaklaşmamı gerekir? Konusunda çalışmalar yapllabilir."

ÖĞTR3: "Bir eğitim almadım ama böyle bir eğitimin gerekli olduğunu düşünüyorum. Dil bazında ve kültürel olarak yapılmalı. Irak'tan, Suriye'den, Afganistan'dan, Iran'dan gelen talebelerin farklı kültürleri var. Onları anlamada zorluk çektiklerini düşünüyorum ve böyle bir eğitimin iyi olacağını düşünüyorum."

ÖĞTR5: "Hayır almadım. Bize bu kişiler hakkında bilgilendirme yapılabilir. Bu çocukların sosyal kültürel yapısı, ekonomik yapısı, hangi milletten olduğu ile ilgili bir bilgilendirme yapılırsa iyi olur. Artık bu bilgilendirmeyi emniyet mi yapar? Milli eğitim mi yapar? Onları kim iyi tanıyorsa onlar bize bir bilgi vermeli. Biz öğrencinin kim olduğunu bilmemiz lazım. Böyle düşünüyorum yani."

ÖĞRT6: "Hayır, bir eğitim almadım. Yabancı dil eğitimi konusunda çocuklarla anlaşamıyoruz. Anlamıyoruz ne konuştuklarını. Ama böyle bir eğitim almak için de dil eğitimi kolay bir şey değil. Onun da kolay kolay alınacak bir durumu yok. Yani o yüzden de hizmet içi eğitimin çok fazla faydalı olacağına inanmıyorum."

ÖĞRT4: "Almadım. Bence böyle bir eğitime gerek yok. Çünkü onların varlı̆̆ına gerek yok ülkemizde."

Öğretmenlerin yabancı uyruklu öğrencilerle ilgili bir eğitim almadığı, genelde böyle bir eğitimin yararlı olacağı görüşünün olduğu görülmektedir. En büyük eğitim ihtiyacının dil konusunda olduğu ancak gelen öğrencilerin dilinin öğrenilmesinin kolay olmadığı bu yüzden hizmet içi eğitim yapılacaksa gelen öğrencilerin sahip olduğu kültürlerin tanıtımı, bu öğrencilere nasıl yaklaşılması gerektiği gibi konularda yapılması gerektiği anlaşılmaktadır.

\section{Yönetici Görüşleri}

Yöneticilerin Hizmet İçi Eğitim İhtiyacı ve Motivasyonu, Okul Kurallarına ve Düzenine Uyum, Etnik gruplaşmalar, Sosyal ve Sportif Faaliyetlere Katılım, İletişim, Aile Desteği, Yabancı Uyruklu Öğrencilere Karşı Genel Tutum, Maddi Sorunlar, Okula Kayıt başlıkları altında bulgular değerlendirilmiştir

\section{Okula Kayıt}

Yabancı uyruklu öğrencilerin okula kayıtları sırasında yaşanılan sorunların ne olduğunu belirlemek amaciyla okul yöneticilerine sorulan sorulara verilen cevaplar şu şekildedir. Yöneticiler genel olarak; denklik ile ilgili sıkıntılar olduğunu ve velilerin kayıt prosedürünü bilmediklerini belirtmişlerdir.

YÖN2: "Yabancı uyruklu öğrenciler okula kayıt yapılırken sadece doğum tarihine bakllmakta ve yaşından bir seviye alta kaydedilmekte. Bu durum ise anlaşmazlı, okula uyumsuzluk problemi oluşturmaktadır."

YÖN7: "Yaşadığımız en büyük sorun şu: Yaşı çok büyük olmasına rağmen denklik nedeniyle yaşının uygun olmadı̆̆ı sınıflara geliyor öğrenciler. Sürekli bunu yaşıyoruz." 
YÖN8: "Denklik komisyonunun ögrenci değerlendirme konusunda yetkin olduğunu düşünmüyorum. Çocuk gerçekten 6. sınıfta olabiliyor ancak bunu 5. sınıfa gönderiyor. Büyük ihtimal bu dil meselesini göz önünde bulunduruyorlar. Irak'ta 6 sene okumuş, biz de 5. sinifa gönderiliyor. Illerleyen dönemlerde bu çocuklar daha iri çocuklar oluyor. Onların beklentileri farklı oluyor. Bazı problemler de yaşanabiliyor."

YÖN3: "Denklik işlemlerinde bazen kaçıncı sinıfta olduğunu belirlemek de zorlanıyoruz. Denklik belgesi geç gelebiliyor. Bu durumda çocuğun kaçıncı sınıfa kayıt olacağın bilemiyoruz. Milli Ĕgitim'e sorduğumuzda onlar da bazen doğru bilgi veremiyor."

YÖN6: “...veliler öncelikle okula gelip kayıt yaptırmak istiyorlar. Sinıf seviyeleri belli

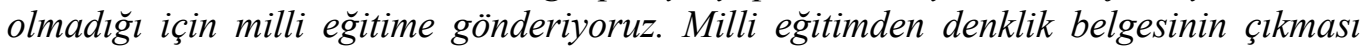
zaman alabiliyor. Bazen çıkan denklik belgesindeki sınıfa itiraz ediyorlar. Bazen de biz seviyeye itiraz ediyoruz."

Yöneticilerin kayıtla ilgili yaşadığı en büyük sorunun öğrencilerin denkliğinin doğru yapılmaması sebebiyle kayıt yapılan sınıfta yaşıtlarından büyük olmaları olarak görünmektedir. Yine yaşanılan iletişim sorunu ve velilerin kayıt için öncelikle nereye başvuracağını bilememesi gibi sorunlar da yaşanmaktadır. Yöneticilerin iletişim sorununu okulda diğer yabancı öğrenciler yardımıyla çözmeye çalıştıkları, bazen de denklik kararlarına itirazda bulundukları anlaşılmaktadır.

Okul Kurallarına ve Düzenine Uyum

Bu problemle ilgili yönetici görüşleri dört başl1k altında sunulmuştur.

\section{Okul kültürü ve kurallarına uyum}

Öğrencilerin okul kurallarına uyma konusunda yaşanılan sorunları tespit etmek için okul yöneticilerine sorulan sorulara verilen cevaplar şu şekildedir. Yöneticiler genel olarak; Türkçe bilmediklerinden ve geldikleri ülkedeki farklı kurallara alışmalarından dolayı sorunların olduğunu söylemişlerdir.

YÖN3: "Okul kültürüne kurallarına uyumunda çok problem yaşlyoruz. Dil bilmedikleri için söylediklerimizi anlamadıkları için de hani hasta olup bilinci açı olup kendisini ifade edemeyen insanlar gibi sinıfin bir köşesinde kallyorlar. Bazen yapma dediğimiz şeyleri yapıyorlar. Ama neden yapmamaları gerektiğini anlatamıyoruz. Mesela küfür etme davranışları olabiliyor, arkadaşlarına zarar verme davranışları olabiliyor. Uyum süreçlerini kolaylaştırmak için en fazla yapabildiğimiz şey rehber ögretmenin yanına yolluyoruz. $O$ da onların dilini anlamadiğı için bir çözüm bulamıyor. Bazen Arapça ögretmenlerimizle iletişim kurmaya çalışıyoruz. Bazıları belli bir düzeyde İngilizce biliyor. Ingilizce öğretmenimizle bağlantı kurmaya çalışıyoruz. Onun dışında diğer sınıf arkadaşlarına da arkadaşımıza sahip çıkın onunla ilgilenin gibi uyarılar yapıyoruz. Yaptığımı faaliyetlere çok etkin olmamakla birlikte onları da katıyoruz."

YÖN2: "Yabancı uyruklu ögrrencilerin okul kültürüne/kurallarına uyumunda ki en büyük problem dil konusu. Dil bilmedikleri için ya sessiz bir şekilde sinufta oturma ya da yanlı̧̧ anlama nedeniyle bizim ögrencilerimizle kavga etme gibi problemler oluşturmakta. Yine okula uyum sağlamama nedeniyle devamsızlık yapmaktalar bu da okul kültürünü ögrenmeden uzaklaşmalarına sebep olmakta. Özel bir etkinlik yok ama tüm etkinliklerde ögrencilerimizle birebir görev almaktalar."

YÖN4: "Ĕ̆er öğrencinin hemen denkliği verilip bize geldiyse çocuğun okula adaptasyonu, Türkçe ile ilgili yaşadığı sıkntılar ve oradaki okul ortamı ile buradaki okul ortamı arasındaki farklılıklar uyum noktasında problemler oluşturuyor. Ama eğer ilkokuldayken ögrenci buraya gelmiş ve biraz Türkçe biliyorsa okul ortamı ile ilgili bir alışmışlı̆̆ varsa herhangi bir problem yaşamıyoruz. Uyum süreçlerini kolaylaştırmak adına veli ziyareti yapıyoruz. Aileyi bulunduğu ortamda görüyoruz. Onlarla tanışıyoruz. ...bir sportif ya sosyal faaliyete yönlendiriyoruz ki daha çok okulda dursun, daha çok arkadaş edinsin. Özellikle sportif faaliyetlere yönlendiriyoruz."

YÖN5: Böyle kavgalar tartışmalar yaşandı̆̆ında rehber ögretmenlerimiz rehberlik faaliyetinde bulunuyorlar. Bizler de söylüyoruz veya velisini çă̆ırarak bilgilendirmede bulmuyoruz. Bu şekilde yapmaması gerektiğini, kavga etmemeleri gerektiğini, bir sorunları olduğunda bizlere, rehber öğretmene ya da sinı öğretmenine söylemeleri gerektiğini söylüyoruz. 
YÖN1: "Belirli zamanlarda aynı ülkeden gelen ögrencilerle okul kurallart ve uyumu ile ilgili ögrrencilere bilgilendirme toplantılart yapılmakta. Türkçe bilmeyenlere Türkçe dil kursu açılmıştır."

Elde dilen veriler değerlendirildiğinde okul kültürüne ve kurallarına uyumda en önemli sorun yabanc1 öğrencilerin Türkçe bilmemeleri olarak ifade edilmiştir. İkinci sırada gelen sorun ise şiddet olarak görünmektedir. Devamsızlık yapmaları, geldikleri yerdeki okul kurallarının farklı olması da diğer sorunlar olarak sıralanmaktadır. Okul yöneticilerinin bu sorunları aşmak için okul içinde çeşitli çözümler bulmaya çalıştıkları anlaşılmaktadır.

\section{Okul klyafetine uyma}

Yabancı uyruklu öğrencilerin okulun belirlediği kıyafet kurallarına uyumla ilgili sorunlarını tespit etmek için okul yöneticilerine sorulan sorulara verilen cevaplar şu şekildedir. Yöneticilerin tamamı öğrencilerin okul kıyafetini maddi imkânsızlıklar sebebiyle alamadığı bu sebeple formasız olarak okula geldiği yönünde görüş bildirmiştir. Ayrıca yöneticiler genel olarak; bu sorunu Okul-Aile Birliği bütçesinden ve öğretmenlerin oluşturduğu fondan çözüme kavuşturmaya çalıştıklarını belirtmişlerdir.

YÖN5: "Okulumuzun belirlediği bir klyafet var. Yabancı uyruklu öğrencilerden maddi durumu iyi olmayanlar bazen okul klyafeti giymeden gelebiliyorlar. Geçtiğimiz yıllarda mezun olan ögrencilerimizin getirdiği klyafetler var. Bu klyafetlerden veriyoruz veya giyim mağazalarında nazımızın geçtiği yerleri arayarak yardımcı olmalarını sağlıyoruz. Onların okul klyafetine uygun kılık klyafetle gelmelerini sağlamaya çalışıyoruz. Bunun dışında ögretmen arkadaşlar ve biz her ay yardım fonu düzenliyoruz. Genelde yabancl uyruklu ögrencilerimize bu fondan elektrik paralarını, su paralarını, giyim, klyafet, yiyecek, konularında yardımcı oluyoruz. Ramazanda bilhassa fitre, zekât gibi yardımlarda bulunuyoruz. Geçen sene yabancı uyruklu ögrencilerimizin hemen hemen hepsine yardımda bulunduk. Maddi imkânı olup okul klyafeti olanlar o klyafeti giyerek geliyorlar. Maddi imkânı olmayanlara da bu şekilde yardımcı oluyoruz."

YÖN3: "Okulumuzun belirlediği bir klyafet var. Yabancı uyruklu ögrrenciler genelde maddi durumları iyi olmadı̆̆ için bizden klyafet talebinde bulunuyorlar. Ĕger elimizde varsa veriyoruz, yoksa almaları için yönlendiriyoruz. Genelde de alamiyorlar. Alamadıkları için sene boyunca kot pantolonla gelen, tişörtle gelen ögrencilerimiz oluyor maalesef. $O$ da maddi durumları iyi olmadı̆̆ için. Alacak güçleri olsa alacaklar. Bazen okulumuzda yardım topluyoruz, yardımcı oluyoruz. O şekilde de klyafet aldı̆̆ımız ögrenciler oluyor. Bizim aldı̆̆ımız kıyafetleri giyiyorlar."

YÖN1: "Okulun belirlediği okul klyafeti bulunmakta. Ancak bu ögrencilerin maddi durumlarl yeterli olmadiğ için bir kısmı okul kıyafetini temin edememekte. Bu tür ögrencilere çevre imkânları kullanılarak okul kıyafeti temin etmekteyiz. Fakat bazı ögrenciler klyafet kurallarına uymamakta ısrar etmekteler. Geldikleri ülkenin kuralları farkl olmast nedeniyle, kendi ülkelerinde rahat ve kuralsı yaşamanın verdiği alışkanlıklar kıyafet kuralına uymamayı beraberinde getirmiştir."

YÖN2: "Okulun kendi klyafeti var. Uyma konusunda problem yaşlyorlar. Maddi problemden dolayı alamadıklarını belirtiyorlar. Kıyafet alındığında bile giymeme konusunda israrcı davranıyorlar. Sanırım serbest klyafetle dolaşma isteği."

YÖN8: "Okulumuzun belirlediği bir klyafet var, öğrenciler bu klyafete uyuyorlar. Ama ögrenci uyumsuzsa, aileden kaynaklanan bazı problemleri de varsa onlar okul klyafetini giymeyebiliyor. Tedarik ediyorsun, allyorsun, aldirlyorsun bir baklyorsun altına kot pantolon giymiş. Bu bizim Türk ögrencilerde de var. Yabancı uyruklu ögrencilerden son derece okul kurallarına uyan tertemiz klyafetleri ile gelen ögrenciler de var."

Yabancı öğrencilerin okul kıyafetini maddi imkânsızlıklar sebebiyle alamadığını ancak kıyafet temin edildiğinde de geldikleri ülkedeki kuralsızlık, rahat yaşama gibi sebeplerle giymek istemedikleri görülmektedir. Yöneticilerin öğrencilerin yaşadığı maddi sorunları Okul-Aile Birlikleri, öğretmenler ve çevreden sağladıkları yardımlarla çözmeye çalıştıkları anlaşılmaktadır.

\section{Devamsızlık ve okul terki}

Yabancı öğrencilerin devamsızlık ve okul terki gibi durumlarını tespit etmek ve bu sorunun Türk öğrencilerle karşılaştırmasını yapmak için okul yöneticilerine sorulan sorulara verilen cevaplar şu şekildedir. Yöneticilerin tamamı öğrencilerin okula devamsızlıkları ve okul terklerinin olduğunu 
söylemişlerdir. Ayrıca genel olarak; maddi imkânsızlıklar, aile ilgisizliği gibi sebeplerden devamsızlığın yaşandığını belirtmişlerdir.

YÖN1: "Yabancı ögrencilerin devamsızlık problemleri kendi ögrencilerimize göre daha fazla. Öğrencilerin bir kısmı aileleri tarafindan zaman zaman çeşitli alanlarda çalıştırılıyor. Bir klsmı ailelerine tercümanlık yapmak için hastaneye ve diğer kurumlara gitmekteler."

YÖN6: "Yabancı uyruklu ögrencilerin devamsızlı yüksek. Dolaylsiyla okul terki de yüksek. Okula ve çevreye uyum săglayamamalart, arkadaş edinememeleri, Türkçeyi ögrenememeleri, derslerde başarısız olmaları, ailenin ilgisizliği sebepler arasında sayllabilir."

YÖN3: "Yabancı uyruklu öğrencilerimizin bazılarının annesi, babası ölmüş. Yetim ve öksüz olan ögrrencilerimiz var. Ailesini savaşlarda kaybetmis ve bu yüzden amcasının yanında, halasının yanında, dayısının yanında yaşayan öğrencilerimiz var. Sabahları sürekli geç gelen ögrencilerimiz var. O yüzden evde nasıl bir ortamlarl var bilmiyoruz. Okula devam etmeyen ögrencilerimiz var. Bunun sebebi anne baba olmamast ve maddi imkânsızlıklar. Kimisi de dolmuşa binemiyor, ta nereden yürüyüp gelmek zorunda kalıyor. Derse gecikiyor ya da gitmesem ne olacak diyor. Devamsızlık Türk ögrenciler ile karşılaş̧tırıldı̆̆ında yabancı uyruklu ögrencilerde daha fazla."

YÖN4: "Devamsizlık noktasında problem yaşlyoruz. Tabii bu sürekli devamsız ögrencilerle ilgili yaşadı̆̆ımız problemin sebebi yurtdışına tekrar kendi vatanlarına dönmeleri. Ya da yurt dışında herhangi bir ülkeye Birleşmiş Milletler tarafindan yerleştirilmeleri. Bununla ilgili bize bilgi gelmediği için sürekli devamsız olarak değerlendiriyoruz. Yabancı uyruklu ögrenciler de sürekli devamsızlık biraz daha fazla. Okula uyumla ilgili problemler yaşandığında devamsızlık ortaya çılkıor. Bu noktada tedbirimiz öncelikle dediüim gibi velilerle görüşüyoruz arkasından resmi işlemleri başlatıyoruz."

Yöneticilerin tamamı yabancı öğrencilerin okula devam ve okul terki konusunda sorun yaşadığını bildirmiştir. Yabancı öğrencilerdeki devamsızlık ve okul terkinin Türk öğrencilerle kıyaslandığında fazla olduğu görülmektedir.

\section{Etnik gruplaşmalar}

Aynı ülkeden gelmiş, aynı dili konuşan yabancı uyruklu öğrenciler arasında bir gruplaşma olup olmadığını; varsa bu durumun okul yönetiminde sorun oluşturup oluşturmadığını öğrenmek için okul yöneticilerine sorulan sorulara verilen cevaplar şu şekildedir. Yöneticilerin tamamı gruplaşmanın olduğunu dile getirmişlerdir. Bir kısmı bunu problem olmadığını belirtirken bir kısmı da problem oluşturduğunu söylemişlerdir.

YÖN2: "Yabancı uyruklu öğrenciler arasında etnik kimliğe dayalı gruplaşmalar oluyor. Ancak bu daha çok bizim ögrrencilerle değil de iki farkll yabancı ülke ögrrencileri arasında daha çok oluyor. (Irakll-Afgan gibi). Bu durum okul idaresi için sorun oluşturuyor. Sürekli kavga olması disiplinsizlik sorununu meydana getiriyor. Kendi öğrencilerimizde disiplin konusunda olumsuz etkiliyor."

YÖN7: "Bu sene Afgan ögrrencilerde bir gruplaşma oldu. Daha önce olmamışt. Afgan ögrencilerin bir araya gelerek Türk öğrencileri slkıştırdıklarına da şahit olduk. Bir ögrencimizi mesela sene sonuna doğru hepsi toplanıp sılkıștırmışlar. Bu gruplaşma yabancı uyruklu öğrencilerin sayıları çoğalınca başladı. Irak, İran, Afgan, Suriyeli hepsinden var. Bir ara Somalili de vardl."

YÖN5: "Bizim okulumuzda yabancı uyruklu öğrenciler arasında etnik kimliğe dayalı bir gruplaşma olduğunu düşünmüyorum. Ama her şey dile dayandiğı için teneffüslerde filan onlar bir araya gelerek oynuyorlar. Bu durum yabancı uyruklu-Türk çatışmasına dönüşecek bir şey değil. O şekilde iletişimleri daha kolay olduğu için teneffüslerde falan bir araya geliyorlar Bu etnik bir durum değil bir gruplaşma şeklinde değil."

Yabancı uyruklu öğrenci sayısı diğer okullara göre daha fazla olan okullarda yabancı öğrenciler arasında etnik kimliğe dayalı gruplaşmaların olduğu, bu durumun başka bir etnik kimliğe sahip yabancı ögrencilerle veya Türk öğrencilerle çatışma zemini oluşturabildiği görülmüştür. Yabancı öğrenci sayısı 
on beşin altında olan iki okulda ise yabancı uyruklu öğrenciler arasında etnik kimliğe dayalı bir gruplaşmanın olmadığı ve sorun yaşanmadığı gözlemlenmiştir.

\section{Sosyal ve Sportif Faaliyetlere Katılım}

Yabancı uyruklu öğrencilerin okullardaki faaliyetlere katılımı konusunda yaşanan sorunlar olup olmadığını tespit etmek amacıyla okul yöneticilerine sorulan sorulara verilen cevaplar şu şekildedir. Yöneticiler genel olarak öğrencilerin bu faaliyetlere katıldıklarını ve okulların bu konuda yabancı öğrencileri teşvik ettiğini belirtmişleridir.

YÖN1: "Okulumuzda her türlü faaliyete yabancı ögrenciler de katılım sağllyor. Gerek sportif faaliyetler gerekse halk oyunları ve koro çalışmaları gibi kültürel faaliyetlere katıllyorlar. Katılımda istekli oluyorlar."

YÖN3: "İlgisi olan ögrrenciler katılmak istiyor. Dilini geliştirmiş olan öğrenciler özellikle katılmak istiyor. Türkçe bilmeyen ögrenciler hiçbir şeye katılmak istemiyor. Ne derse katıliyorlar ne sportif faaliyete ne sosyal faaliyetlere hiçbir şeye katılmiyorlar."

YÖN8: "Dil problemini çözmüş olan çocuklar her türlü faaliyete gönüllü katılmak istiyorlar. Israrla istiyorlar. Korodan spor faaliyetlerine kadar, şiire kadar her türlü faaliyete katıllyorlar. Biz de teşvik ediyoruz. Hatta İstiklal Marşı söylüyorlar, bayră̆ı tutuyorlar. “

YÖN7: "Yabancı öğrencilerin sporla alakaları yok. Çok nadir bir iki tane çıktı şimdiye kadar. O da bir tanesi futbolda kalecimiz yoktu kaleci oldu. 51 tane yabancı ögrencimiz vardı bu sene. 51 ögrenciden 1 tanesi oranlayın işte. Diğerleri bir faaliyete katılmadı."

Yabancı uyruklu öğrencilerin sosyal, sportif ve kültürel etkinliklere çoğunlukla katılmak istedikleri, Türkçe öğrenen öğrencilerde daha fazla istek olduğu, okul yönetici ve öğretmenlerinin bu konuda yabancı öğrencilere bir ayrımda bulunmadığı, hatta teşvik ettiği görülmüştür.

\section{İletişim}

Yabancı uyruklu öğrencilerin sorunlarını ve isteklerini okul yöneticilerine iletip iletemedikleri, bu konuda yaşanan sorunları öğrenmek amaciyla okul yöneticilerine sorulan sorulara verilen cevaplar şu şekildedir. Yöneticilerin çoğunluğu öğrencilerin Türkçe biliyorsa kendileri bilmiyorlarsa bilen arkadaşları vasıtasıyla sorunlarını ve isteklerini iletebildiklerini, bu konuda sorun yaşanmadığını söylemişlerdir.

YÖN1: "İstek ve sorunlarını rahatlıkla iletiyorlar. Türkçe bilmiyorsa bilen bir arkadaşı vasitasiyla bize sözel olarak iletiyorlar. Hiçbir şekilde güçlük çekmiyorlar."

YÖN7: "Yabancı uyruklu öğrencilerden Türkçeyi iyi bilen bir kaç sene önce buraya gelen ögrencilerimiz var. İlk başta geldiklerinde Türkçeyi çözene kadar onların aracıllğ̆yla anlaşabiliyoruz. Ondan sonra da zaten Türkçeyi ögrrendiklerinde sıkıntı olmuyor çok. Kendileri gelip sıkıntılarını söylüyorlar. Herhangi bir çekingenlikleri korkulart yok. Bizden çok daha rahatlar yani."

YÖN8: "İmam Hatip Ortaokulu olduğumuzdan bizim Arapça ögretmenimiz var veya meslek dersi öğretmenleri. ...bir şekilde iletişim kuruyoruz. Bu konuda bir sikıntı yaşamadık. Geliyor bir problemi olursa. Ben hemen Arapça öğretmenini artyorum. O da geliyor. Problemimizi hallediyoruz. Türkçe bilenler rahatça dertlerini anlattyorlar."

YÖN3: "Türkçe bilmeyenler sorunlarını iletemiyor maalesef. Diğerleri bizim ögrencilerimizle aynı. Bir sorun yaşamıyoruz. Ama dili olmayan öğrenciler arkadaşıyla kavga ediyor anlatamıyor. Sorun yaşlyor anlatamiyor. Kalemim yok diyemiyor. Parası yok açım diyemiyor. Gerçekten bu konuda sorun yaşıyoruz. Sadece bakışıyoruz. Savaş görmüş çocuklarımızda çekingenlikler olabiliyor. Konuşmuyorlar, son derece içlerine kapanık oluyorlar. Tepki bile vermiyorlar yani."

Yabancı uyruklu öğrencilerin özellikle Türkçe öğrendikten sonra sorunlarını ve isteklerini okul yöneticilerine rahatlıkla anlatabildikleri, bu konuda yaşanan iletişim problemlerini de çeşitli yollarla çözdükleri görülmektedir.

\section{Aile Desteği}

Yabancı uyruklu öğrenci ailelerinin eğitim sürecine desteklerinin olup olmadığını bu konuda yaşanan sorunları öğrenmek amacıyla okul yöneticilerine sorulan sorulara verilen cevaplar şu şekildedir. 
Yöneticilerin çoğunluğu aile desteğinin düşük olduğunu ve desteğin ailenin maddi durumu ve eğitim seviyesine göre değiştiğini dile getirmiştir.

YÖN4: "Eğer öğrenci ilkokul eğitimi almışsa veya bir seneye yakın bir eğitimi bizim okullarımızda görmüşse bazı velilerimiz, bunların sayısı çok değil, gelip ögrencinin durumunu soruyorlar. Rehberlik servisine yönlendirdiğimiz velilerimiz var. Ders durumunu takip eden velilerimiz var. Ama bu velilerin sayısı dil problemi sebebiyle tabii ki düşük."

YÖN5: "Maddi durumu iyi olan öğrencilerin için velileri katkı sağllyorlar. Devamını sağllyorlar. Kurslara katılımlarını sağlıyorlar. Dilimizi bilen ve maddi durumu iyi olan veliler gerekli katklyı sağllyorlar. Ama dilimizi bilmeyen veliler gerekli katkıyı sağlayamıyorlar. Onlarla zaten anlaşamıyoruz. Onlar yardımcı olamıyor çocuklarına. Ama diğerleri bizim Türk öğrencilerimiz gibi kılık klyafetleri düzgün. Hiçbir sıkıntı yaşamadı̆̆ımız Iraklı öğrencilerimiz var. Bizim öğrencilerimizin çoğu Iraklı."

YÖN8: "Ailelerin aynen bizde olduğu gibi ilgilisi var, ilgisizi var, hiç okula uğramayanı var. İki günde bir gelen veli de var, veli toplantılarina katılan veli de var. Ama ne çektiklerini bilmiyoruz yani. Okulumuzda bir aileden, kardeş çocuklarl, okula gelen 2 ögrenci var. Bir seferinde ben evlerine gitmiştim. Çalışan bir tane adam ne kadar para getirir eve bilmiyorum. Ama evin durumu pekiyi değil yani. Çok kötüydü. Yataklar bir tarafa yiğılmış, ayakkabıyla giriyorlar içeri. Bu durumda olan aileler ilgisiz. Daha önceden gelip iş bulan maddi durumu iyi olan aileler takibini de yapıyor çocuklarının. Yabancı uyruklu öğrencilerde ailesi ilgili olan yarı yarıya diyebilirim. Anasınıfinda bir ögrencimiz vardı. Okula gelmemeye başladı. Okul aidatını karşılayamıyorlarmış. Veliyi çă̆ırıp konuştuk. Durumu kendisine anlatınca ağlamaya başladı. Sonra yeter ki gelsin, biz para istemiyoruz senden dedik."

YÖN7: "Sadece sosyal yardımlaşmadan yardım alacakları zaman öğrenci belgesi almak için geliyorlar. Onun dışında hiçbir şekilde görmüyoruz. Adam okulun adını da bilmiyordur, hangi sınıfa gittiğini de bilmiyor çocuğunun."

Yabancı uyruklu öğrenci ailelerinin eğitim sürecine desteğinin düşük olduğu ortaya çıkmaktadır. Destek veren ailelerin ise maddi anlamda durumlarının iyi olduğu anlaşılmaktadır. Gelir seviyesi düşük, maddi sıkıntısı olan ailelerin çocuklarının eğitim sürecine destek olamadıkları görülmektedir.

\section{Yabancı Uyruklu Öğrencilere Karşı Genel Tutum}

Yabanc1 uyruklu öğrencilerin okulda Türk öğrencilerle beraber eğitim almasına tepkilerini öğrenmek, hangi uygulamanın daha yararlı olduğunu tespit etmek ve velilerin bu konudaki tepki ortaya koyup koymadığını anlamak amacıyla okul yöneticilerine sorulan sorulara verilen cevaplar şu şekildedir. Yöneticilerin çoğunluğu Türk öğrencilerle beraber eğitim almanın daha yararlı olacağını ifade etmişlerdir. Fakat yabancı öğrencilerin okulda bulunmalarına Türk öğrenci velilerinin olumsuz tepkiler verdiğini söylemișlerdir.

YÖN2: "Ayrı bir okul uygulaması tamamen kopmalarına, yaşadıkları yerin kurallarına uymaları konusunda sıkıntı yaşanmasına neden olur. Bence ülkeye ilk geldiklerinde direk okula gönderilme yerine dil ögrenme, toplum kurallarını öğrenme gibi temel becerilerin ögretileceği kurslara gönderilip daha sonra okullara seviyelerine uygun bir sinav yapılıp, bu sinavi da gideceği okulun komisyonun yapması şartlyya uygun olduklarl sinıflara yerleştirmeli. Birlikte eğitim almaları konusunda genel anlamda bir şikâyet yok. Ancak sayıları okullara eşti miktarda dağıtılmadı̆ğnda okul yabancılar okulu pozisyonuna girme gibi bir duruma yöneliyor. Bu durumda başarılı ögrencilerin başka okullara gitmesine neden oluyor."

YÖN5: "Bu konuda ben Türk ögrenciler ile beraber eğitim almalarının daha doğru olacağını düşünüyorum. Türkiye’ye entegre olmaları açısından, kültürümüzü ögrenmeleri açısından yani değerlerimizi, bizim Türk toplumumuzun özelliklerini ögrrenmeleri açısından şimdiki uygulamanın daha doğru olduğunu düşünüyorum. Yabancı uyruklularla Türk ögrencilerin beraber eğitim almaları konusunda bazı velilerimizin tepkileri oluyor tabi. Bunun nedeni de yabancı öğrencilerin aşılarının olmamasl, temizliğe, hijyene dikkat etmeleri. Mesela bizim okulumuzda bu ara el ayak 
hastalı̆̆ı diye bir hastalı zuhur etti. Genelde bunun yabancı uyruklu ögrencilerden gelen bir hastalık olduğunu bildikleri için tepki gösteriyorlar."

YÖN7: "Kesinlikle ayrı bir okul uygulamasının iyi olacağını düşünüyorum. Bunun başka bir ilde yapıldığını ve çok da başarılı olduklarını duydum. Hiç dil bilmeyen bizim örfümüzü, âdetinizi, kültürümüzü bilmeyenler okulumuza geliyor. Yaşları da çok büyük. Bazen sakalları çımış çocuklar geliyor bizim 6. ve 8. sinıflarımıza. Benim çocuğum da 7. sınıfta. Onlarla aynı okulda okumalarını istemiyorum. Çocuk hırlı mı hırsız mı, terörist mi kimin çocuğu olduğu belli değil. Ben yabancı ögrencilerin ĕger bu ülkeden gönderilemiyorsa ayrı müstakil bir okulda okumalarının doğru olacağını düşünüyorum. Devaml farklı bir okulda, müstakil, onlara ait bir okulda okumalarını istiyorum, hiç bize karışmasinlar. Hatta mümkünse ülkemizden gitsinler yani. Bazı sınıflarımızda yabancl uyruklu öğrenci saylst diğer sinıflara göre biraz fazla ise o sinıfi tercih etmemeye çalışıyor veliler. Hatta okulumuzda yabancı uyruklu öğrenci sayısının artması sebebiyle sizin okulunuzda çok yabancı varmış. Bu yüzden problemler çoğalmış, deyip de okulumuza kayıttan vazgeçme sebebi olarak görenler bile oluyor."

Okul yöneticilerinde bazı okullarda yığılmaya mahal verilmeyecek şekilde yabancı öğrencilerin Türk ögrencilerle beraber eğitim almaları gerektiği, böylece uyum sorunlarının daha aza indirileceği, ayrı olması halinde toplumdan daha da kopuk hale geleceği kanaatinin fazla olduğu; velilerin Türk ögrencilerle beraber eğitim alma konusunda genelde olumsuz tepki vermedikleri görülmüsstür.

\section{Maddi Sorunlar}

Yabanc1 uyruklu öğrenci ailelerinin maddi sorunlarını öğrenmek, bu konuda okuldan istekleri olup olmadığı belirlemek amaciyla okul yöneticilerine sorulan sorulara verilen cevaplar şu şekildedir. Yöneticilerin çoğunluğu ailelerin maddi anlamda sıkıntı çektiklerini ve bu konuda okuldan özellikle okul ihtiyaçları için yardım talebinde bulunduklarını söylemişlerdir.

YÖN5: "Okulumuzdaki yabancı uyruklu ögrencilerin yüzde doksanının maddi durumları iyi değil. Orada maddi durumu iyi olup da buraya gelen ögrencilerimiz yüzde on civarında. Maddi durumu iyi olmayan ögrencilere burada yardımcı oluyoruz yiyecek konusunda, giyecek konusunda. Genelde de ögrenciler kaylt olduktan sonra öğrenci belgesi alarak Sosyal Yardımlaşma Vakfindan yardım isteğinde bulunuyorlar. Bizlerden de ara sıra doğalgaz aboneliğini alamadım, su ve elektrik parasını yatırmadım diye talepleri oluyor. Biz de okulumuzdaki yardım fonundan yardımci oluyoruz. Veli ziyaretleri de yaptı̆̆ımızda gerçekten de durumun böyle olduğunu gördüğ̈̈müz, içimizin acıdlğı velilerimiz oldu. Evinde eşyası olmayan, sobası olmayan, yakıtı olmayan veliler gördügümüz de bunlara yardımcı olmaya çalıştık ve olduk da."

YÖN7: "Hepsinin istekleri var çoğunun yani \%95'inin maddi durumu kötü. Sürekli Sosyal Yardımlaşma Vakfina başvuruyorlar. Bizim de kendi okulumuzun oluşturduğu bir fon var veya başka kuruluşlardan gelen yardımlar var. Onları da yabancı ögrencilere vermeye çalı̧̧ıoruz."

YÖN3: "Genelde gelir seviyeleri düşük. Genelde yardım altyorlar ve sanayide, inşaatlarda falan çalışmak zorunda kalıyor erkekler. Erkeği olmayan bayanlar da akrabalarının yanında olduğu için onların durumu hepten kötü zaten. Ramazan ayında fitre verir misiniz? Ayakkabı alır misınız? Servis parası veremiyorum gibi istekleri çok oluyor. Ama biz yardımci oluyoruz."

Yönetici görüşlerine göre yabancı uyruklu öğrenci ailelerinin genelde maddi sıkıntı çektikleri, özellikle okul ihtiyaçları için okullardan yardım talebinde bulundukları; okulların ise bu yardım taleplerine cevap vermek için öğretmenler arasında para topladıkları, kıyafet topladıkları, bunları ihtiyacı olan öğrenci ve ailelerine dağıttıkları görülmektedir.

\section{Yöneticilerin Hizmet İçi Eğitim İhtiyacı ve Motivasyonu}

Bu alt problemle ilgili yönetici görüşleri iki başlık altında sunulmuştur.

\section{Hizmet içi eğitim ihtiyacı}

Yabancı uyruklu öğrencilerin bulunduğu okullarda çalışan okul yöneticilerinin farklı kültürlerden gelen bu öğrencilere eğitim verme konusunda bir eğitim alıp almadıklarını ve böyle bir eğitime ihtiyaç duyup 
duymadıklarını tespit etmek amacıyla okul yöneticilerine sorulan sorulara verilen cevaplar şu şekildedir. Yöneticilerin tamamı böyle bir eğitim almadıklarını ve verilmesinin faydalı olacağını belirtmişlerdir.

YÖN1: "Yönetici olarak eğitim almadım. Kesinlikle eğitim verilmeli. Bir takım kültürel farklilıkları bilmemiz gerekmekte."

YÖN4: "Biz doğrudan bu konuyla bağlantıl bir eğitim almadik. Tabii ki verilmeli. Faydalı olacağını düşünüyorum. Sonuçta son beş yılda karşılaştı̆̆ımız bir durum bu. Kendi öğrencilik dönemlerimizde veya idareciliğe başladı̆̆ımızda bu tür şeyler yoktu. Biz bu konuda kendimiz yaşantımızla ve tecrübelerimizle yön vermeye çalışıyoruz. Yeni tecrübeler ediniyoruz."

YÖN3: "Biz herhangi bir eğitim almadı. Bence kesinlikle eğitim verilmeli. Çünkü her okulumuzda yabancı ögrenciler var. Öğretmenlerin ve yöneticilerin nasıl davranması gerektiğini profesyonel bir şekilde öğrenmeleri lazım. Çünkü bu çocuklara da bizim ihtiyacımız var. Kaybediyoruz, eriyorlar. Yani sınıfin içinde okulun içinde kaynaştırma ögrencileriyle ne kadar ilgilenemiyorsak bu ögrencilerle de ilgilenemiyoruz. Eriyip gidiyorlar. Yazı oluyor."

Okul yöneticilerinin hiç birinin yabancı uyruklu öğrencilerin eğitimiyle ilgili bir eğitim almadıkları ve tamamının bu öğrencilere nasıl davranılması gerektiği, gelen öğrencilerin kültürleriyle ilgili bilgi verilmesi, öğrencilerle daha sağlıklı iletişimler kurulabilmesi gibi konularda böyle bir eğitimin iyi olacağını düşündükleri anlaşılmaktadır.

\section{Motivasyon}

Yabanc1 uyruklu öğrencilerin bulunduğu okullarda görev yapan yöneticilerin motivasyonlarının olumlu ya da olumsuz etkilenip etkilenmediğini tespit etmek amaciyla okul yöneticilerine sorulan sorulara verilen cevaplar şu şekildedir. Yöneticilerin çoğunluğu motivasyonlarının olumsuz etkilendiğini bazıları da herhangi bir etkisi olmadığını dile getirmiştir. Bir yöneticinin de olumlu yönde etkilediğini belirtmesi dikkat çekicidir.

YÖN1: "Zaman zaman olumsuz yönde motivasyon düşüyor. Kurallarl öğretmekte zorlanıyoruz. Yaptığımız çalı̧̧maların birçoğu boşta kalıyor."

YÖN3: "Benim motivasyonumu açıkçası duygusal açıdan etkiliyor. Şöyle, onları görünce inanılmaz canım sıkllıyor. Yardımcı olamadığımı düşünüyorum. Ne yapmam gerektiğini bilmiyorum. Onları hani biraz olsun güldürmek biraz olsun neşelendirmek için ne yapabilirim, neden hoşlanırlar, hiçbir fikrim yok. O da benim gerçekten motivasyonumu düşünüyor yani. Koridorda görüyorum herkes koşuyor oynuyor, o eli cebinde boynu bükük duruyor bir köşede. Yani yardımcı olamadıkça ben üzülüyorum."

YÖN5: “...okulumuzda 800 tane ögrenci var bunlardan 27 tanesi yabancı uyruklu. Biz çok fazla sorun yaşamıyoruz. Sayı itibariyle az olduğu için motivasyon konusunda bize hiçbir etkisi yok. Yabancı ögrenci sayısı çok olan okullarda bazı arkadaşlarımız bu tür problemlerle karşılaşabilir. Sayıları az olduğu için her sınıftan birer ikişer yabancı ögrrenci var. Diğerlerinin içinde kayboluyor."

YÖN8: "Olumlu yönde etkiliyor. Türk kültürünü aktardlğımız için ben mutlu oluyorum. Onlardaki değişimi görünce ben mutlu oluyorum. Onların Istiklal Marşı söylemeleri bayrak tutmaları beni mutlu ediyor. Bayramlara katılmalar mutlu ediyor."

Yabancı öğrenci sayısının fazla olduğu okullarda görev yapan yöneticilerin bu durumdan kaynaklı sorunlar sebebiyle olumsuz etkilendikleri ancak yabanc1 uyruklu öğrenci sayısı az olan okullarda yabancı uyruklu öğrencilerin yöneticilerin motivasyonuna bir etkisinin olmadığı görülmektedir.

\section{Tartışma ve Sonuç}

Öğretmen ve yöneticilerden elde edilen bulguların tartışmaları iki alt başlıkta ele alınmıştır.

\section{Öğretmen Görüşleri}

Öğretmenlerin tamamının yabancı uyruklu öğrencilerin bulunduğu sınıflarda çeşitli sorunlar yaşadığı görülmüştür. Öğretmenlerin dile getirdiği sorunlar arasında ön plana çıkan, öğrencilerin Türkçe bilmemeleri ve buna bağlı olarak yaşanılan iletişim sorunudur. Zayimoğlu Öztürk (2018) mülteci öğrencilere sunulan eğitim-öğretim hizmetinin sosyal bilgiler öğretmen görüşlerine göre değerlendirilmesi konulu çalışmasında; öğrencilerin eğitim sistemi içerisinde yaşadıkları en temel ve en 
önemli sorunun dil sorunu olduğunu ifade etmektedir. Nar'ın (2008) öğretmenlerle yaptığı çalışması da göçle gelen öğrencilerin dil sorunu yaşadığını ortaya koymuştur. Sarıtaş, Şahin ve Çatalbaş'ın (2016) yabancı uyruklu öğrencilerin bulunduğu okullardaki öğretmen ve yöneticilerle yaptığı çalışmada ögretmen ve yöneticiler yabancı uyruklu öğrencilerle ilk aşamada karşılaştıkları sorunun dil farklılığı olduğunu vurgulamışlardır. Bu çalışmalar da bu araştırmanın bulgularıyla örtüşmektedir.

Öğretmenler; yabancı uyruklu öğrencilerde söz dinlememe, yaramazlık yapma, şiddete yanlısı olma, sayılarının çoğalmasıyla beraber kendi soydaşı olan öğrencilerle gruplaşma ve çeteleşme gibi sorunların görüldüğünü söylemişlerdir. Öğrencilerin şiddete meyilli olmalarının sebebinin yaşadıkları savaş, göç vb. travmalar ve öğrencinin kişilik özelliğine bağlı olabileceği belirtilmiştir. Sarıtaş, Şahin ve Çatalbaş’a (2016) göre öğretmenler; yabancı uyruklu öğrencilerde şiddet eğilimi, çeteleşme, saldırganlık, kural tanımama, gelişimsel farklılığın getirdiği bazı sorunlarla karşı karşıya kalmaktadır. Yine Nar'ın (2008) göçün eğitime ve eğitim yönetimine etkileri başlıklı çalışmasında öğretmenlerin, yabancı uyruklu ögrencilerin birbirleriyle şiddet içerikli oyunlar oynadıklarını ve bu öğrenciler arasında genelde kendi memleketinden olan arkadaşlarıyla çeteleşmeye varabilen gruplaşmalar olduğunu söylemesi bizim araştırmamızla benzer sonuçlar ortaya koymaktadır. Delen (2018) yaptığı çalışmada Türk ve yabancı uyruklu öğrencilerin genellikle; birbirlerini şikâyet ettiklerini, arkadaşlarının ve öğretmenin sözünü kestiklerini, birbirleriyle konuştuklarını, sınıf içi etkinliklerde pasif ve isteksiz davrandıklarını, ders dışı şeylerle ilgilendiklerini, ödevlerini gelişi güzel yaptıklarını ve sürekli konuşarak diğer arkadaşlarını çalışmalarında rahatsız ettiklerini belirtmiştir. Kaya ve Ok'un (2021) çalışmasında matematik ve fen bilimleri öğretmenlerinin sözlü iletişimde yetersizlik, sosyal ilişkilerde zayıflık, öğrenme ortamından kopukluk gibi nedenleri dil ve iletişimdeki uyum sorunları; dersi anlamada yaşanan güçlükler, okuma yazmada yaşanan sorunlar, öğrenme ortamının gerisinde kalınması ve ödev yapmada yaşanan sorunları ise akademik sorunlarda yaşanan uyum sorunları olarak gördüğü belirtilmektedir.

Öğretmenler; öğrencilerin Türkçe bilmemelerinin isteklerini anlatmaya engel olduğu, özellikle sözel derslerde başarıyı düşürdügü, okula devamsızlık yapmaya sebep olduğunu ayrıca öğrencilerde Türkçe öğrenme ve eğitim alma konusunda bir gayretin olmadığı ifade etmişlerdir. Delen (2018) çalışmasında bazı yabancı uyruklu öğrencilerin Türkçe bilmemelerinden dolayı, özellikle sözel derslerde sıkıldıklarını ve dersi anlamadıklarını ifade etmektedir. Zayimoğlu Öztürk (2018) ise mülteci öğrencilere sunulan eğitim-öğretim hizmetleriyle ilgili Sosyal Bilgiler öğretmenlerinin görüşlerini değerlendirdiği çalışmasında mülteci öğrencilerin eğitim sistemi içerisinde yaşadıkları en temel ve en önemli sorunun dil sorunu olduğunu; dersten sıkılma, dersi anlamama, kabullenilme ve uyum sorunlarının temelinde dil sorununun yattığını ifade etmektedir. Bu çalışmaların bizim bulgularımızla benzer sonuçlar ortaya koyduğu görülmektedir.

Yabanc1 uyruklu öğrencilerin içinde az da olsa derslerinde başarılı olan öğrencilerin olduğu, bunun yanında başarısız öğrencilerin de olduğu görülmüştür. Öğrencilerin Matematik derslerinde matematik işlemlerini yaptığı ancak Türkçeyi iyi bilmediği için problemlerde zorlandığı, Türkçe derslerinde ise dile bağlı olarak başarılarının düşük olduğu, çocuk sayısı az olan ailelerdeki öğrencilerin daha başarılı olduğu ortaya çıkmıştır. Öğretmenlere yabancı uyruklu öğrenci ailelerinin eğitim sürecine destekleri olup olmadığı sorulduğunda ise ailelerin fazla bir desteğinin olmadığını sonucu ortaya çıkmıştır. Benzer şekilde Güngör ve Şenel (2018) yabanc1 uyruklu ilkokul öğrencilerinin eğitim-öğretiminde yaşanan sorunları incelediği çalışmasında ailelerin oldukça ilgisiz olduğu, okula gelmedikleri, öğretmen ile iletişim kurmadıkları ve çocuklarının ödevlerine de yardımcı olmadıkları sonucuna ulaşmıştır.

Öğretmenler yabancı uyruklu öğrencilerin zaman zaman Türk arkadaşları tarafından dışlandığını söylemektedir. Türk öğrencilerin anne ve babalarının ise yabancı öğrencilerin okullarda bulunmasına bir tepkilerinin olmadığı anlaşılmaktadır. Nar'ın (2008) çalışmasında öğretmenler, öğrencilerin farklı kültürel özelliklerinden dolayı dışlanma ve etiketlenme davranışlarına maruz kaldıklarını belirtmiştir. Öğretmenlerin görüşlerine göre, yabancı uyruklu öğrencilerin ülkemize geldiği ilk yıllarda ayrı okul veya sınıflarda eğitim alarak Türkçe öğrenmeleri gerektiği, daha sonraki yıllarda ise topluma uyum sağlamaları için mutlaka Türk öğrencilerin olduğu okullarda eğitim almaları ortaya çıkmıştır. Yani ilk yıllarda ayrı okul uygulaması doğru bulunurken ileriki yıllarda yabancı uyruklu öğrenciler için ayrı okul uygulamasına olumlu bakılmamaktadırlar.

Öğretmenlere yabanc1 uyruklu öğrenci ailelerinin maddi durumu sorulduğunda; maddi anlamda iyi durumda olan aileler olsa da bu ailelerin sayılarının az olduğu, genelde yabancı uyruklu öğrenciler ve ailelerinin maddi sıkıntılar yaşadığı, bu sıkıntıların devlet ve hayır kurumları tarafından yapılan yardımlarla büyük ölçüde giderildiği, hayatlarını desteklerle sürdürdükleri görülmüş̧tür. 
Öğretmenlerin genelde sınıflarında yabancı uyruklu öğrencilerin olmasından olumlu veya olumsuz olarak etkilenmedikleri, bazı öğretmenlerin onların durumuna acıyarak duygusal anlamda etkilendikleri, sınıflarda yabancı uyruklu öğrenci sayısının artmasıyla beraber istenmeyen davranışlar nedeniyle olumsuz etkilenmeler olduğu ortaya çıkmıştır. Şensin (2016) tarafından yapılan benzer bir araştırmada öğretmenler, yabanc1 uyruklu öğrencilerden duygusal olarak ve motivasyon olarak olumsuz etkilendiklerini ayrıca bu sebepten dolayı kendilerini yorgun hissettiklerini belirtmişlerdir.

Öğretmenler yabancı uyruklu öğrencilerle ilgili bir eğitim almadığı, genelde böyle bir eğitimin yararlı olacağ1 görüşünü ifade etmişlerdir. Hizmet içi eğitim yapılacaksa; gelen öğrencilerin sahip olduğu kültürlerin tanıtımı, bu öğrencilere nasıl yaklaşılması gibi konularda yapılması gerektiği ifade edilmiştir. Delen'in (2018) çalışmasında öğretmenler, yabancı uyruklu öğrencilerin Türk eğitim sistemine daha hızlı ve etkili bir şekilde dâhil edilebilmesi için; öğretmenlerin hizmet içi eğitim seminerlerine alınmaları, yabancı uyruklu öğrencilere etkili ders anlatabilmeleri için daha verimli yöntem ve tekniklerin öğretilmesi gerektiğini ifade etmişlerdir. Yiğit (2015) yaptığı çalışmada öğretmenlerin, sığınmacı çocukların eğitimlerine yönelik kurs almadıklarından ve dil farklılığından dolayı çok kültürlü sınıflarda eğitim verme ve sınıf yönetimi konusunda zorluklarla karşılaştıkları sonucuna ulaşılmıştır. $\mathrm{Bu}$ çalışmalar bizim araştırma bulgularımıza benzerdir.

\section{Yönetici Görüşleri}

Okul yöneticileri, öğrencilerin denkliğinin doğru yapılmaması sebebiyle kayıt yapılan sınıfta yaşıtlarından büyük olmalarının önemli bir sorun olduğunu; yine yaşanılan iletişim sorunu ve velilerin kayıt için öncelikle nereye başvuracağını bilememesi gibi sorunların da yaşandığını ifade etmişlerdir. Yöneticilerin iletişim sorununu okulda diğer yabancı öğrenciler yardımıyla çözmeye çalıştıkları, bazen de denklik kararlarına itirazda bulundukları anlaşılmaktadır. Sarıtaş ve diğerleri (2016) yaptıkları çalışmada öğrencilerin denkliklerinin sağlanmasında yöneticilerin ikilem yaşadığını, yaşı büyük çocukların denklik komisyonlarınca küçük sınıflara yerleştirildiği için sorun yaşandığını söylemektedir. Levent ve Çayak'ın (2017) yaptığı çalışmada; okul yöneticileri, Suriyeli öğrencilerin eğitiminde denklik sorununun yaşandığına dikkat çekmiştir.

Yabancı uyruklu öğrencilerin okul kurallarına ve düzenine uyumda en önemli sorun öğrencilerin Türkçe bilmemeleridir. İkinci sırada gelen sorun ise şiddet olarak görünmektedir. Devamsızlık yapmaları, geldikleri yerdeki okul kurallarının farklı olması da diğer sorunlar olarak sıralanmaktadır. Yapılan görüşmelere bakıldığında okul yöneticilerinin bu sorunları aşmak ve uyum sürecini kolaylaştırmak için; rehber öğretmenlerden yardım aldıkları, sınıf arkadaşlarına yeni gelen öğrenciye sahip çıkmaları konusunda telkinde bulundukları, yapılan etkinliklere yabancı ögrencileri de kattıkları, veli ziyaretleri yaptıkları, öğrencilere okul kurallarını anlattıkları, Türkçe kursu açtıkları görülmektedir.

Yöneticilerin tamamı yabancı öğrencilerin okula devam ve okul terki konusunda sorun yaşadığını bildirmiştir. Yabancı öğrencilerdeki devamsızlık ve okul terki Türk öğrencilerle kıyaslandığında fazla olarak görülmektedir. Bu bulguyla paralel olarak Kaştan ve Bozan'ın (2016) yoğun göçün eğitime ve eğitim yönetimine etkisini incelediği çalışmasında göçle gelen öğrencilerin devamsızlık sorunlarının fazla olduğu ortaya çıkmışır.

Yöneticiler, yabancı öğrencilerin okul kıyafetini maddi imkânsızlıklar sebebiyle alamadığını ancak kıyafet temin edildiğinde de geldikleri ülkedeki kuralsızlık, rahat yaşama gibi sebeplerle giymek istemediklerini ifade etmişlerdir. Yöneticilerin öğrencilerin yaşadığı maddi sorunları okul-aile birlikleri, ögretmenler ve çevreden sağladıkları yardımlarla çözmeye çalıştıkları anlaşılmaktadır. Bu bulguya paralel olarak; Levent ve Çayak (2017) Suriyeli öğrencilerle ilgili olarak dil, kültür ve yaşam tarzlarının farklı oluşu nedeniyle Türk toplumuna uyum sağlamada zorlandıklarını belirtmiştir.

Yöneticilerle yapılan görüşmelerde yabancı uyruklu öğrenci sayısı fazla olan okullarda yabancı öğrenciler arasında etnik kimliğe dayalı gruplaşmaların olduğu, bu durumun başka bir etnik kimliğe sahip yabancı öğrencilerle veya Türk öğrencilerle çatışma zemini oluşturabildiği görülmüştür. Yabancı öğrenci sayısı on beşin altında olan iki okulda ise yabancı uyruklu öğrenciler arasında bir gruplaşmanın olmadığı ve sorun yaşanmadığı gözlemlenmiştir. Nar'ın (2008) araştırmasındaki bulguları, araştırma bulgularımızla örtüşmektedir. Nar, araştırmasında yabancı uyruklu öğrenciler arasında genelde kendi memleketinden olan arkadaşlarıyla çeteleşmeye varabilen gruplaşmalar görüldügünü ifade etmektedir. Yabancı uyruklu öğrencilerin sosyal, sportif ve kültürel etkinliklere çoğunlukla katılmak istedikleri, Türkçe öğrenen öğrencilerde daha fazla istek olduğu, okul yönetici ve öğretmenlerinin bu konuda yabancı öğrencilere bir ayrımda bulunmadığı, hatta teşvik ettiği görülmüştür. Yiğit (2015) yaptığı 
çalışmada sığınmacı öğrencilerin, okullarda düzenlenen sosyal-kültürel faaliyetlere katılmaya istekli olduğu ve etkinliklerde yer aldığı sonucuna ulaşmıştır.

Yöneticiler, ailelerin eğitim sürecine desteğinin düşük olduğunu ifade etmişlerdir. Destek veren ailelerin maddi durumlarının iyi olduğunu belirtmişlerdir. Bu konuyla ilgili olarak Nar'ın (2008) çalışması evde Türkçe bilen olmadığından dolayı öğrencilerin derslerine ailenin yardımcı olamadığını ortaya koymuştur. Güngör ve Şenel (2018) de yabanc1 uyruklu öğrenci velilerinin okula gelmediklerini, çocuklarıyla ilgilenmediklerini ve derslerinde yardımcı olmadıklarını ifade etmektedir. Sarıtaş ve diğerlerinin (2016) çalışması yabancı uyruklu öğrencilerin velileri ile iletişim sorunları yaşandığını, velilerin öğrencilerin dersleriyle ilgilenmediğini, ödev takibi yapmadıklarını ortaya koymuștur.

Yöneticiler, yabancı uyruklu öğrencilerin Türk öğrencilerle beraber eğitim almaları gerektiği ancak bazı okullarda yığılma olmayacak şekilde düzenleme yapılmasının şart olduğunu belirtmişlerdir. Böylece uyum sorunlarının daha aza indirileceği, okulların ayrı olması halinde yabancı öğrencilerin toplumdan daha da kopuk hale geleceği kanaatinin olduğu görülmektedir. Türk öğrenci velilerinin ise yabanc1 öğrencilerin Türk öğrencilerle beraber eğitim alma konusunda genelde olumsuz tepki vermedikleri görülmüştür. Eren (2019) devlet okullarında göçmen öğrencilerin sınıflara dengeli bir biçimde dağıtıldığını, bu uygulamanın göçmen öğrencilerin okula ve sınıfa uyumunu kolaylaştırdığını belirttiği çalışması bizim araştırmamızla örtüşmektedir.

Yöneticiler; yabancı uyruklu öğrenci ailelerinin genelde maddi sıkıntı çektiklerini, özellikle okul ihtiyaçları için kendilerinden yardım talebinde bulunduklarını söylemişlerdir. Okul yöneticilerinin ise bu yardım taleplerine cevap vermek için gönüllülük esasına dayalı olarak öğretmenler arasında para topladıkları, kıyafet topladıkları, bunları ihtiyacı olan öğrenci ve ailelerine dağıttıkları görülmektedir. $\mathrm{Bu}$ sonuçla benzer olarak Sarıtaş ve diğerleri (2016) öğrenci velilerinin ekonomik yetersizlikleri nedeniyle ders araç-gereci temin edemediklerini belirtmiştir.

Özellikle yabancı öğrenci sayısının fazla olduğu okullarda görev yapan yöneticilerin bu durumdan kaynaklı sorunlar sebebiyle olumsuz etkilendikleri ancak yabancı uyruklu öğrenci sayısı az olan okullarda yöneticilerin motivasyonunda bir etkilenme olmadığ görülmektedir. Buna göre yabanc1 uyruklu öğrencilerin beli okullarda yığılmasının önüne geçecek tedbirlerin alınması gerektiği ortaya çıkmaktadır. Güngör ve Şenel (2018) yabancı uyruklu öğrencilerin belirli okullara yığılmaması ya da bu öğrenciler için ayrı okulların belirlenmesi ve öğrencilerin okullara dağıtımında sistematik bir düzenleme yapılmasını önermektedir.

Okul yöneticileri, yabancı uyruklu öğrencilerle ilgili bir eğitim almadıklarını ifade etmişlerdir. Yöneticiler bu öğrencilere nasıl davranılması gerektiği, gelen öğrencilerin kültürleriyle ilgili ve öğrencilerle daha sağlıklı iletişimler kurulabilmesi gibi konularda eğitim verilmesinin iyi olacağını söylemişlerdir. Levent ve Çayak'ın (2017) Türkiye'deki Suriyeli öğrencilerin eğitimine yönelik çalışması bu bulguyu desteklemektedir. Çalışmada okul yöneticilerine ve öğretmenlere Suriyeli öğrencilerin geldiği kültür ile Türk öğrencilerin geldiği kültür çerçevesinde eğitim hizmetini en iyi şekilde sunabilmeleri için çok kültürlü eğitim seminerleri verilmesi gerektiği ifade edilmektedir.

Sonuç olarak okullarında yabancı uyruklu öğrencisi bulunan yönetici ve öğretmenlerin çeşitli sorunlarla karşı karşıya oldukları, bu sorunların bir kısmını kendi imkânları ölçüsünde çözdükleri, bazılarına ise çözüm bulamadıkları görülmektedir. Sarıahmetoğlu ve Kamer'in (2020) öğrenci görüşlerine yönelik çalışmasında da öğrencilerin görüşleriyle öğretmen ve yöneticilerin görüşleri örtüşmektedir. Ayrıca öğretmenler ve yöneticiler yabancı uyruklu öğrencilerin ve ailelerinin kültürünün, dilinin, maddi durumlarının farklı olduklarını vurgulamışlardır. Bu konuda Şahin ve Eşici (2020) birlikte yaşam kültürü üzerinde değerlerin belirleyici bir rolünün bulunduğunu, benzerlikleri firsata dönüştürmenin, engel olarak görülen farklılıkların farkında olmanın ve bunlara yönelik politikalar geliştirmenin önemli olduğunu ve kolektif yaşantıların geliştikçe, ortak değerlerin ortaya çıkacağını ve buna bağlı olarak birlikte yaşam kültürünün oluşacağını ifade etmiş̧lerdir.

Araştırma sonuçlarına göre uygulayıcılara ve araştırmacılara şu öneriler yapılabilir: Ülkemize yeni gelen öğrenci ve ailelerini okullara yönlendirecek ve kayıt sırasında yardımcı olacak bir rehberlik faaliyetinin sağlanması ve Türkçe eğitimi, uyum eğitimi, psikolojik destek vb. verilmesi gibi gerekli önlemlerin alınması gerekmektedir. Araştırma yapılacak okullar seçilirken yabancı uyruklu öğrencilerin yoğun olduğu okullar tercih edilmiştir. Yabancı uyruklu öğrencisi olmayan veya çok az olan okullar da katılarak bu okullar arası karşılaştırmalar yapılabilir. 


\section{Kaynakça}

Akar, H. (2016). Durum çalışması. Eğitimde nitel araştırma desenleri (Ed: A. Saban ve A. Ersoy). Ankara: An1 Yayınc1lik.

Baker, C. (2011). Foundations of Bilingual Education and Bilingualism, Clevedon, UK: Multilingual Matters.

Büyüköztürk Ş., Kılıç Çakmak, E. ve Demirel, F. (2009). Bilimsel araştırma yöntemleri (3. Bask1). Ankara: Pegem Akademi.

Creswell, J.W. (2013). Araştırma deseni. (S. B. Demir, Çev. Ed.). Ankara: Eğiten Kitap

Delen, A. (2018). Yabancı uyruklu öğrencilerin bulunduğu ilkokullarda istenmeyen öğrenci davranışlarının incelenmesi. (Yayımlanmamış yüksek lisans tezi). Atatürk Üniversitesi Eğitim Bilimleri Enstitüsü, Erzurum.

Dupper, D. R. (2002). School social work: Skills and interventions for effective practices. New Jersey: John Wiley \& Sons, Inc.

Duygu, H. (2016). Alanya örneğinde yabancı uyruklu ortaokul öğrencilerinin karşılaştıkları sorunlar. (Yayımlanmamış yüksek lisans tezi). Abant İzzet Baysal Üniversitesi Eğitim Bilimleri Enstitüsü, Bolu.

Emiroğlu Erol, S. (2018). Suriyeli sığınmacı çocukların eğitimi ve sorunları. (Yayımlanmamış yüksek lisans tezi). Akdeniz Üniversitesi Eğitim Bilimleri Enstitüsü, Antalya.

Erdem, C. (2017). Sınıfında mülteci öğrenci bulunan sınıf öğretmenlerinin yaşadıkları öğretimsel sorunlar ve çözüme dair önerileri. Medeniyet Eğitim Araştırmaları Dergisi, 1(1), $26-42$.

Eren, Z. (2019). Yönetici ve öğretmen görüşlerine göre göçmen çocukların eğitim sorunları ve çözüm önerileri. Bolu Abant İzzet Baysal Üniversitesi Eğitim Fakültesi Dergisi, 19(1), 213-234.

Güngör, F. ve Şenel, E. A. (2018). Yabancı uyruklu ilkokul öğrencilerinin eğitim öğretiminde yaşanan sorunlara ilişkin öğretmen ve öğrenci görüşleri, AJESI - Anadolu Journal of Educational Sciences International, 8(2), 124-173.

Karasar, N. (2015). Bilimsel araştırma yöntemi (28. Basım). Ankara: Nobel Yayınları.

Kaştan, Y. (2015).Türkiye'de göç yaşamış çocukların eğitim sürecinde karşılaşılan problemler. Uluslararası Sosyal ve Eğitim Bilimleri Dergisi. 2 (4), 2015-229.

Kaştan, Y. ve Bozan, İ. (2016). Yöneticiler açısından göçün yönetim üzerine etkisi. Uluslararası Sosyal ve Ĕgitim Bilimleri Dergisi, 3(5),104-129.

Kaya, D., ve Ok, G. (2021). Problems encountered by mathematics and science teachers in classrooms where Syrian students under temporary protection status are educated and suggestions for solution. International Journal of Contemporary Educational Research, 8(1), 111-127. DOI: https://doi.org/10.33200/ijcer.774094

Levent, F. ve Çayak, S. (2017). Türkiye'deki Suriyeli öğrencilerin eğitimine yönelik okul yöneticilerinin görüşleri. Hasan Ali Yücel Eğitim Fakültesi Dergisi, 14(27), 21-46.

Nar, B. (2008). Göçün eğitime ve eğitim yönetimine etkileri. (Yayımlanmamış yüksek lisans tezi). Sakarya Üniversitesi Sosyal Bilimler Enstitüsü. Sakarya.

Özcan, A. (2018). Çokkültürlülük bağlamında Türkiye'nin Suriyeli öğrencilere yönelik eğitim politikası. Uluslararası Sosyal Araştırmalar Dergisi, 4 (1), 17-29.

Paker, T. (2015). Durum çalışması. F. N. Seggie ve Y. Bayyurt (Ed.), Nitel araştırma yöntem, teknik, analiz ve yaklaşımları. Ankara: Anı Yayıncılık.

Patton, M. Q. (2014). Nitel araştırma ve değerlendirme yöntemleri (M. Bütün ve S. B. Demir, Çev.). Ankara: Pegem Akademi.

Pennells, J. ve Chimah, E. (2002). Basic education for refugees and nomads. C. Yates and J. Bradley (Ed.) In Basic Education at a Distance: World Review of Distance Education and Open Learning. Vol. 2, (193-180). London: Routledge.

Sarıahmetoğlu H. ve Kamer, S. T. (2020). Yabanc1 uyruklu ortaokul öğrencilerinin eğitim sürecinde karşılaştıkları sorunlara ilişkin görüşleri. Elektronik Sosyal Bilimler Dergisi. Ekim (2020) - Cilt: 19 Say1:76.

Sarıtaş, E., Şahin, Ü. ve Çatalbaş, G. (2016). İlkokullarda yabancı uyruklu öğrencilerle karşılaşılan sorunlar. Pamukkale Üniversitesi Sosyal Bilimler Enstitüsü Dergisi, 25(1), 208-229. 
Sayın, Y., Usanmaz A. ve Aslangiri, F. (2016). Uluslararası göç olgusu ve yol açtığı etkiler: Suriye göçü örneği. Karamanoğlu Mehmet Bey Üniversitesi Sosyal ve Ekonomik Araşstırmalar Dergisi, 18 (31), 1-13.

Solak E. ve Çelik, S. (2018). Türkiye'de eğitim gören mülteci öğrencilerin dilsel sorunlarının incelenmesi. Uluslararası Sosyal Araştırmalar Dergisi, 11(57), 424-432.

Stevenson, J. ve Willot, J. (2007). The aspiration and access to higher education of teenage refugees in the UK. Compare, 37(5), 671-687.

Stuecker, J. (2006). Education of refugees. Iowa, US: Iowa Statewide Parent Information Resource Center Program. https://pdfs.semanticscholar.org/88e0/5ffbad7cc81c2f480cf1e2b331fb711fe929.pdf

Şahin, M. ve Eşici H. (2020). Türkiye'de Yaşayan Suriyeli Göçmenler İle Türklerin Birlikte Yaşam Kültürü: Değerler, Fırsatlar, Engeller. AVRASYA Uluslararası Araştırmalar Dergisi Cilt: 8 Say1: 22 Sayfa: 72 - 99

Şensin, C. (2016). Sınıf öğretmenlerinin Suriye'den göçle gelen öğrencilerin eğitimlerine ilişkin görüşlerinin değerlendirilmesi. (Yayımlanmamış yüksek lisans tezi). Uludağ Üniversitesi Eğitim Bilimleri Enstitüsü. Bursa.

Turan, M. ve Polat, F . (2017). Türkiye'de öğrenim gören yabanc1 uyruklu ilköğretim öğrencilerinin karş1laştıkları sorunlar ve çözüm önerileri. Qualitative Studies, 12 (4), 31-60.

Tuncer, M. (2016). Göçmenlere yönelik eğitim ve eğitim programları. Eğitime Baklş Dergisi, 12(36), 9-13.

Tuncer, M. ve Dikmen, M. (2017). Göçmenlerin eğitim sorunları ve çözüm önerileri. 11. Kamu Yönetimi Sempozyumu. 28-30 Eylül Elazığ. Türkiye

Yıldırım, A. ve Şimşek, H. (2016). Sosyal bilimlerde nitel araştırma yöntemleri. (10. Baskı). Ankara: Seçkin Yayınevi.

Yiğit, T. (2015). Uygulamalar ve sorunlar bağlamında Türkiye'de sığınmacı çocukların eğitimi. (Yayınlanmamış yüksek lisans tezi). Ahi Evran Üniversitesi Sosyal Bilimler Enstitüsü. Kırşehir.

Zayimoğlu Öztürk, F. (2018) Mülteci öğrencilere sunulan eğitim-öğretim hizmetinin sosyal bilgiler öğretmen görüşlerine göre değerlendirilmesi. AJESI - Anadolu Journal of Educational Sciences International, 8(1) 52-79.

\section{Extended Abstract}

\section{Introduction}

Migration to Turkey has started in recent years due to the turmoil in neighboring countries, especially in Syria. This situation was seen as temporary, and long-term policies for asylum seekers were not produced. This perception has also shown itself in the education system. Today, foreign students who have immigrated to our country for various reasons have attended the same schools and classes as Turkish students. Considering the situation of these students, it is very difficult for them to be exposed to the same curriculum as Turkish students without any help. Considering that they are culturally different and have lived in the war for a long time, it is seen that the level of knowledge of these students is lower than their Turkish peers. Therefore, the current situation of these students should be determined and educational content should be presented accordingly. Teachers, unlike their students, try to solve the language problems of foreign students with their efforts. The different cultures of foreign students, staying away from school during the migration process, and the fact that some of them have never started school negatively affect the schools, students, and teachers in the country of immigration.

This study aims to determine the problems faced by teachers and school administrators in the adaptation of foreign students studying in secondary schools in Kastamonu province to the education system, and to identify possible solutions related to these problems.

\section{Methodology}

This study is qualitative in nature. The face-to-face interview method was used through multiple holistic case studies. Having the highest number of foreign students at secondary school in Kastamonu province was determined as a criterion and schools were selected accordingly. The questions in the interview forms were posed to two teachers and two administrators from four selected schools, based upon their 
voluntariness. The data were obtained from the interviews with eight teachers, and eight school administrators in Kastamonu province in 2018. Interviews were conducted through a semi-structured interview form prepared by the researcher. The descriptive analysis method was used to analyze the data obtained from the audio-recorded interviews.

\section{Findings and Discussion}

According to the results, it became clear that foreign students' poor command of Turkish is the most important problem encountered by teachers and school administrators. For this reason, these students fail academically and are initially excluded by their friends. The high number of foreign students in schools increases the incidence of violence and gang involvement among students. It was found that the absenteeism rate and dropout rate of these students are high and the families of these students are in financial difficulties. It was observed that the enrollment of foreign students in the underage ranking classes during the equivalence procedures caused some problems, too. The mass of foreign students in some particular schools has increased the problems and caused new ones. It is seen that the school administrators and teachers who have foreign students in their schools face various problems, they solve some of these problems within their means, and they cannot find a solution to some of them. i

${ }^{\mathrm{i}} \mathrm{Bu}$ makaleye, birinci yazar \% 75 ve ikinci yazar \%25oranında katkı sağlamış olduklarını beyan ederler. 